\title{
Nerve Terminal Nicotinic Acetylcholine Receptors Initiate Quantal GABA Release from Perisomatic Interneurons by Activating Axonal T-Type $\left(\mathrm{Ca}_{\mathrm{v}} 3\right) \mathrm{Ca}^{2+}$ Channels and $\mathrm{Ca}^{2+}$ Release from Stores
}

\author{
Ai-Hui Tang, ${ }^{1,3}$ Miranda A. Karson, ${ }^{1,3}$ Daniel A. Nagode, ${ }^{1,4}$ J. Michael McIntosh, ${ }^{5}$ Victor N. Uebele, ${ }^{6}$ John J. Renger, ${ }^{6}$ \\ Matthias Klugmann, ${ }^{7}$ Teresa A. Milner, ${ }^{8}$ and Bradley E. Alger ${ }^{1,2,3,4}$ \\ Departments of ${ }^{1}$ Physiology and ${ }^{2}$ Psychiatry, Programs in ${ }^{3}$ Neuroscience and ${ }^{4}$ Molecular Medicine, University of Maryland School of Medicine, Baltimore, \\ Maryland 21201, 5Department of Psychiatry, University of Utah, Salt Lake City, Utah 84132, ${ }^{6}$ Merck Research Labs, West Point, Pennsylvania 19486, \\ ${ }^{7}$ Translational Neuroscience Facility, University of New South Wales, Sydney, New South Wales 2052, Australia, and ${ }^{8}$ Department of Neurology and \\ Neuroscience, Weill Cornell Medical College, New York, New York 10065
}

Release of conventional neurotransmitters is mainly controlled by calcium $\left(\mathrm{Ca}^{2+}\right)$ influx via high-voltage-activated (HVA), $\mathrm{Ca}$, 2 , channels ("N-, P/Q-, or R-types") that are opened by action potentials. Regulation of transmission by subthreshold depolarizations does occur, but there is little evidence that low-voltage-activated, $\mathrm{Ca}_{\mathrm{v}} 3$ ("T-type"), channels take part. GABA release from cortical perisomatictargeting interneurons affects numerous physiological processes, and yet its underlying control mechanisms are not fully understood. We investigated whether T-type $\mathrm{Ca}^{2+}$ channels are involved in regulating GABA transmission from these cells in rat hippocampal CA1 using a combination of whole-cell voltage-clamp, multiple-fluorescence confocal microscopy, dual-immunolabeling electronmicroscopy, and optogenetic methods. We show that $\mathrm{Ca}_{\mathrm{v}} 3.1$, T-type $\mathrm{Ca}^{2+}$ channels can be activated by $\alpha 3 \beta 4$ nicotinic acetylcholine receptors (nAChRs) that are located on the synaptic regions of the GABAergic perisomatic-targeting interneuronal axons, including the parvalbumin-expressing cells. Asynchronous, quantal GABA release can be triggered by $\mathrm{Ca}^{2+}$ influx through presynaptic $\mathrm{T}$-type $\mathrm{Ca}{ }^{2+}$ channels, augmented by $\mathrm{Ca}^{2+}$ from internal stores, following focal microiontophoretic activation of the $\alpha 3 \beta 4 \mathrm{nAChRs}$. The resulting GABA release can inhibit pyramidal cells. The T-type $\mathrm{Ca}^{2+}$ channel-dependent mechanism is not dependent on, or accompanied by, HVA channel $\mathrm{Ca}^{2+}$ influx, and is insensitive to agonists of cannabinoid, $\mu$-opioid, or $\mathrm{GABA}_{\mathrm{B}}$ receptors. It may therefore operate in parallel with the normal HVA-dependent processes. The results reveal new aspects of the regulation of GABA transmission and contribute to a deeper understanding of ACh and nicotine actions in CNS.

\section{Introduction}

$\mathrm{Ca}^{2+}$ influx through presynaptic high-voltage-activated (HVA) $\left(\mathrm{Ca}_{\mathrm{v}} 2\right)$ channels is predominantly responsible for release of conventional neurotransmitters (Augustine et al., 2003; Neher and Sakaba, 2008). Inhibition of these channels is the major mecha-

Received June 3, 2011; revised July 19, 2011; accepted July 31, 2011.

Author contributions: A.-H.T., M.A.K., D.A.N., T.A.M., and B.E.A. designed research; A.-H.T., M.A.K., and D.A.N. performed research; J.M.M., V.U., J.R., M.K., and T.A.M. contributed unpublished reagents/analytic tools; A.-H.T., M.A.K., and D.A.N. analyzed data; A.-H.T., M.A.K., D.A.N., and B.E.A. wrote the paper.

This work was supported by NIH Grants R01 MH077277 and R01 DA014625 (B.E.A.), and R01 MH53631 and R01 GM48677 (J.M.M.). Plasmids pAAV-EF1a-double floxed-hChR2 (H134R)-mCherry-WPRE-HGHpA and pAAV-EF1adouble floxed-mCherry-WPRE-HGHpA were obtained from the plasmid-sharing site Addgene, through a material transfer agreement with Dr. K. Deisseroth (Stanford University, Stanford, CA). Antibody 9303 was provided by CURE Digestive Diseases Research Center, Antibody/RIA Core, NIH Grant KD41301. We thank Prof. T. Snutch for advice on the use of the $\mathrm{Ca}_{\mathrm{v}} 3 \mathrm{x}$ antibodies. We are indebted to Drs. Jimok Kim and $\mathrm{Scott}$ Thompson for their valuable comments on a draft of this manuscript.

V.N.U. and J.J.R. are employees of Merck and Co., Inc. (USA), and potentially own stock and/or stock options in the company.

Correspondence should be addressed to Dr. Bradley E. Alger, Department of Physiology, University of Maryland School of Medicine, 655 West Baltimore Street, Room 5-025, Baltimore, MD 21201. E-mail: balgerlab@gmail.com. DOI:10.1523/JNEUROSCI.2781-11.2011

Copyright $\odot 2011$ the authors $\quad 0270-6474 / 11 / 3113546-16 \$ 15.00 / 0$ nism of regulation of neurotransmitter release by G-proteincoupled receptors (GPCRs) on synaptic terminals (Tedford and Zamponi, 2006). Low-voltage-activated $\left(\mathrm{Ca}_{\mathrm{v}} 3\right.$, T-type) $\mathrm{Ca}^{2+}$ channels are generally not involved in evoked neurotransmitter release, although they initiate slow release from nonaxonal sites (Carbone et al., 2006; Cueni et al., 2009). T-type $\mathrm{Ca}^{2+}$ channels differ markedly from HVA channels and if present could confer distinctive properties on synaptic transmission at conventional synapses.

Although HVA channels dominate the release process driven by axonal action potentials, other processes, including modulation by presynaptic neurotransmitter receptors, also regulate release. Presynaptic receptors in the brain are frequently located outside of defined synaptic regions. Indeed, much chemical signaling between neurons occurs "nonsynaptically" (Vizi and Lendvai, 1999), with transmitter being released from sites not apposed to postsynaptic targets and reaching receptors on distant presynaptic nerve terminals. For example, acetylcholine (ACh) influences numerous physiological and pathological processes in the CNS through activation of presynaptic nicotinic acetylcho- 
line receptors (nAChRs) (Albuquerque et al., 2009) that modulate transmitter release (McGehee and Role, 1996; MacDermott et al., 1999). Numerous interneurons express nAChRs (McQuiston and Madison, 1999; Sudweeks and Yakel, 2000), and in cortical regions, perisomatic-targeting interneurons, mainly "basket cells," control principal cell excitability and electrical oscillations implicated in cognitive processing (Klausberger et al., 2005; Freund and Katona, 2007). The links among nicotine and ACh in schizophrenia, memory and learning, and Alzheimer's disease (Albuquerque et al., 2009) make it important to understand regulation of perisomatic cell output by nAChRs.

$\mathrm{Ca}^{2+}$ permeation through the $\alpha 7 \mathrm{nAChR}$ pore induces glutamate release independently of voltage-gated $\mathrm{Ca}^{2+}$ channels (Sharma and Vijayaraghavan, 2003). Non- $\alpha 7$ nAChRs can elicit GABA release from synaptosomes (Wonnacott, 1997; Lu et al., 1998) and some brain regions (Léna and Changeux, 1997; Kawa, 2007; Liu et al., 2007), although the mechanisms of this effect are not well established. Presynaptic nAChRs might be capable of depolarizing synaptic terminals enough to induce release via activation of T-type $\mathrm{Ca}^{2+}$ channels; however, this possibility has received little attention.

We investigated cholinergic regulation of GABA release by activating hippocampal perisomatic GABAergic terminals with focal microiontophoretic ACh application. With a combined electrophysiological, morphological, and optogenetic approach, we find that activation of axonal $\alpha 3 \beta 4 \mathrm{nAChRs}$ can stimulate TTX-insensitive GABA release independently of HVA channels, via a mechanism that depends on $\mathrm{Ca}_{\mathrm{v}} 3.1 \mathrm{~T}$-type $\mathrm{Ca}^{2+}$ channels and $\mathrm{Ca}^{2+}$ from internal stores. This mechanism can be found on parvalbumin (PV)-expressing, perisomatic-targeting interneurons, which are involved in pacing "gamma" rhythm oscillations (Freund, 2003; Klausberger et al., 2005; Bartos et al., 2007; Freund and Katona, 2007; Klausberger and Somogyi, 2008) and are implicated in schizophrenia (Lewis et al., 2005). nAChRevoked IPSCs can inhibit pyramidal cells but are resistant to inhibition by agonists of cannabinoid receptors $\left(\mathrm{CB}_{1} \mathrm{Rs}\right), \mu$-opioid receptors $(\mu \mathrm{ORs})$, or $\mathrm{GABA}_{\mathrm{B}}$ receptors $\left(\mathrm{GABA}_{\mathrm{B}} \mathrm{Rs}\right)$. The $\alpha 3 \beta 4$ $n A C h R-C a_{v} 3.1$ mechanism could act in parallel with $\mathrm{Ca}_{\mathrm{v}} 2$ channels and GPCRs and regulate GABA release.

\section{Materials and Methods}

All animal protocols were performed in accordance with the Guidelines for the Care and Use of Experimental Animals and were approved by the Institutional Animal Care and Use Committee at the University of Maryland School of Medicine (UMSOM).

\section{Slice preparation}

Young (5- to 7-week-old) male Sprague Dawley rats (or virus-infected mice, below) were deeply sedated with isoflurane $\left(2 \%\right.$ in $\left.\mathrm{O}_{2}\right)$ and decapitated. Transverse hippocampal slices ( $400 \mu \mathrm{m}$ thick) were cut on a Vibratome VT1200S (Leica). Slices were placed in a holding chamber at room temperature $\left(22^{\circ} \mathrm{C}\right)$ at the interface of artificial CSF (ACSF) and a humidified gas mixture of $95 \% \mathrm{O}_{2}$ and $5 \% \mathrm{CO}_{2}$ for $\geq 1 \mathrm{~h}$ before use. ACSF contained the following (in mM): $120 \mathrm{NaCl}, 3 \mathrm{KCl}, 2 \mathrm{MgSO}_{4}, 2.5$ $\mathrm{CaCl}_{2}, 1 \mathrm{NaH}_{2} \mathrm{PO}_{4}, 25 \mathrm{NaHCO}_{3}, 20$ glucose, and was bubbled with $95 \%$ $\mathrm{O}_{2}$ and $5 \% \mathrm{CO}_{2}, \mathrm{pH} 7.3$.

\section{Electrophysiology}

Experiments were performed in a submersion-type tissue chamber (model RC-27; Warner Instruments) that was continuously perfused with ACSF at room temperature, $\sim 22^{\circ} \mathrm{C}$. In all experiments on AChevoked GABA release, the voltage-clamped pyramidal cell was filled with the following (in $\mathrm{mm}$ ): 80 Cs methanesulfonate, $50 \mathrm{CsCl}, 10 \mathrm{HEPES}, 3$ ATP-Mg, 0.3 GTP-Tris, $0.1 \mathrm{CaCl}_{2}, 1$ BAPTA-K ${ }_{4}, 1 \mathrm{MgCl}_{2}, 5$ QX-314; $280-290$ mOsm, $\mathrm{pH}$ 7.2. Access resistance $\left(R_{\mathrm{a}}\right)$ was monitored on every sweep, and if $R_{\mathrm{a}}$ changed by $>25 \%$, the records were not used. To measure action potential firing (see Fig. 7), current-clamp recordings were made from pyramidal cells with patch pipettes containing the following (in mM): $146 \mathrm{~K}$-gluconate, $1 \mathrm{NaCl}, 1 \mathrm{MgSO}_{4}, 0.2 \mathrm{CaCl}_{2}, 2$ EGTA, 10 HEPES, 4 ATP-Mg, $0.3 \mathrm{~mm}$ GTP-Tris. This solution preserved the normal $\mathrm{GABA}_{\mathrm{A}} \mathrm{R}$ reversal potential of approximately $-75 \mathrm{mV}$. A Nikon E600 microscope fitted with differential interference contrast optics was used for visually guided patch electrode placement, although in some experiments the "blind" patch method was used. Recordings were made with Axopatch 200B amplifiers (Molecular Devices). Signals were filtered at $2 \mathrm{kHz}$ and digitized at $5 \mathrm{kHz}$ with a Digidata $1440 \mathrm{~A}$ interface and Clampex 10. Spontaneous IPSC frequency was measured with MiniAnalysis (Synaptosoft). The miniature IPSC (mIPSC) peak threshold value was from 6 to $8 \mathrm{pA}$ (measured from the baseline determined from the $2.5 \mathrm{~ms}$ period just before the mIPSC) depending on the cell, and an mIPSC area threshold of $50 \mathrm{fC}$ was set. Each mIPSC detection was visually verified. Timing of action potential firing (see Fig. 7) was analyzed with protocols written in Interactive Data Language (IDL5.5; Research Systems). In all other experiments, Clampfit 10 (Molecular Devices) was used to measure amplitude, total charge, and temporal properties of ACh-evoked responses.

\section{Drug application}

ACh was delivered locally with microiontophoretic pulses through a normal glass pipette containing $20 \mathrm{~mm} \mathrm{ACh}$ and placed within $10-20 \mu \mathrm{m}$ of the recorded pyramidal cell. A constant backing current of $-15 \mathrm{nA}$ prevented ACh leakage, and brief (0.5-1.5 s) positive currents of 300-500 nA were applied at intervals of 1-1.5 min to eject ACh. All other agonists or antagonists were bath-applied for $>10 \mathrm{~min}$. Nifedipine, 1,4-dihydro-2,6-dimethyl5-nitro-4-[2-(trifluoromethyl)phenyl]-3-pyridinecarboxylic acid, methyl ester (Bay K 8644), and 2,5-dimethyl-4-[2-(phenylmethyl)benzoyl]-1 $\mathrm{H}$ pyrrole-3-carboxylic acid methyl ester (FPL 64176) were dissolved in ethanol. 3,5-Dichloro- $N$-[1-(2,2-dimethyl-tetrahydro-pyran-4-ylmethyl)4-fluoro-piperidin-4-ylmethyl]-benzamide (TTA-P2), ryanodine, cyclopiazonic acid (CPA), xestospongin $\mathrm{C}$, and $(R)-(+)-[2,3-$ dihydro-5methyl-3-(4-morpholinylmethyl)pyrrolo[1,2,3-de]-1,4-benzoxazin-6-yl]1-napthalenylmethanone (WIN 55212-2) were dissolved in DMSO. Final concentrations of both vehicles were $<0.1 \%$. EGTA-AM was dissolved in DMSO at $50 \mathrm{~mm}$ and an equal volume of 20\% Pluronic F-127 (SigmaAldrich; in DMSO) before dilution in ACSF. The combination of $0.4 \%$ DMSO and $0.08 \%$ Pluronic F-127 alone did not affect ACh-evoked responses. $\alpha$-Conotoxin AuIB synthesis has been described previously (Luo et al., 1998) and was provided by J.M.M.; TTA-P2 was provided by V.N.U. and J.J.R.; NBQX, APV, and TTX were obtained from Ascent Scientific; EGTA-AM was obtained from Invitrogen; and other drugs used were purchased from Tocris or Sigma-Aldrich.

\section{Intrinsic flavoprotein fluorescence imaging}

Redox fluorometry based on intrinsic fluorescence of oxidized flavoproteins has been used for studying cellular energy metabolism (Shibuki et al., 2003). We used changes in intrinsic flavoprotein fluorescence to estimate the functionally effective spread of ACh released by microiontophoresis. The fluorescence was excited at $450-490 \mathrm{~nm}$ by a mercury lamp and monitored via a 505LP dichroic mirror and a 510-560 nm emission filter through a $60 \times$ water-immersion objective. Images were acquired with a monochrome CCD camera (ORCA; Hamamatsu) at 20 Hz. Data were recorded with $8 \times 8$ binning with Metafluor software (Molecular Devices). Imaging files were analyzed with customized IDL protocols.

\section{Preparation of $A A V$ vectors}

The plasmids pAAV-EF1a-double floxed-hChR2 (H134R)-mCherryWPRE-HGHpA and pAAV-EF1a-double floxed-mCherry-WPREHGHpA (K. Deisseroth, Stanford University, Stanford, CA; Addgene stock 20297 and 20299, respectively) were packaged into AAV pseudotyped vectors (1:1 ratio of AAV1 and AAV2 capsid proteins, with AAV2 inverted-terminal repeats) by methods that have been described previously (Klugmann et al., 2005). The genes encoding mCherry or ChR2-mCherry in these vectors are inverted in the antisense direction and are under the control of a Cre-dependent flip-excision ("FLEX") 
Table 1. Primary antibodies, dilutions, and sources used in experiments (see Materials and Methods), a sample reference in which the specificity of the antibody has been demonstrated, and the method used to validate the specificity of the antibody

\begin{tabular}{|c|c|c|c|c|c|}
\hline Molecule & Species & Dilution & Source & Specificity references & Validation method \\
\hline \multirow[t]{2}{*}{ PV } & Mouse lgG & $1: 10,0001: 3000$ (EM) & Swant, PV-28 & Celio et al., 1988 & Immunoblot of brain and muscle lysates \\
\hline & $\begin{array}{l}\text { Rabbit lgG (used for } \\
\text { PVCre mice) }\end{array}$ & $1: 1000$ & Calbiochem, PC255L & Mithani et al., 1987 & Western blot of rat brain and muscle lysates \\
\hline SYP & Mouse lgM & $1: 5000$ & Millipore, mab sp15 & Honer et al., 1993 & Immunoblot of human brain lysates \\
\hline$C a_{v} 3.1$ & Rabbit lgG & 1:100 & Alomone, ACC-021 & Ernst et al., 2009 & $\begin{array}{l}\text { Western blot of brain lysates from transgenic } \\
\text { mice overexpressing receptor; validated } \\
\text { against } \mathrm{Ca}_{\mathrm{v}} 3.1 \mathrm{KO} \text { mouse (T. Snutch, } \\
\text { personal communication) }\end{array}$ \\
\hline TAU1 & Mouse lgG & 1:5000 & Millipore, mab3420 & Binder et al., 1985 & Immunoblot of rat brain lysates \\
\hline ChAT & Goat lgG & 1:1000 & $\begin{array}{l}\text { Millipore Bioscience Research } \\
\text { Reagents, AB144P }\end{array}$ & $\begin{array}{l}\text { Raised against human placental } \\
\text { enzyme; company tested }\end{array}$ & Western blot of mouse brain lysates \\
\hline
\end{tabular}

switch. Activation of the FLEX switch results in stable gene inversion into the sense direction, and thus gene expression, only in the presence of Cre (Atasoy et al., 2008).

Transgenic mice and $A A V$ injection

ChAT-Cre (B6;129S6-Chat ${ }^{\text {tml (cre)Lowl } / J)}$ and PV-Cre (B6;129P2-

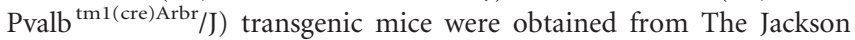
Laboratory (stock 006410 and 008069 , respectively). Homozygous mice were bred and maintained in the animal facility at the UMSOM. Mice were housed on a $12 \mathrm{~h}$ light/dark cycle with food and water ad libitum.

Adult (7- to 16-week-old) mice were anesthetized with ketamine (75 $\mathrm{mg} / \mathrm{kg})$ and acepromazine $(2.5 \mathrm{mg} / \mathrm{kg})$. They were placed in a smallanimal stereotactic instrument (David Kopf Instruments). A small craniotomy was made over the target region with a dental drill, and a glass pipette (tip diameter, $\sim 50 \mu \mathrm{m}$ ) was used to inject a total volume of $0.5-1$ $\mu \mathrm{l}$ of $\operatorname{AAV}\left(5 \times 10^{9}\right.$ genome copies/ $\left./ \mu \mathrm{l}\right)$ at $0.1 \mu \mathrm{l} / \mathrm{min}$ into the medial septum/diagonal band of Broca of ChAT-Cre mice $(+1.0 \mathrm{~mm}$ AP from bregma, $0.0 \mathrm{~mm} \mathrm{~L},-4.2$ to $-3.2 \mathrm{~mm} \mathrm{DV}$ from the dura) or bilaterally into the dorsal hippocampi of PV-Cre mice $(-2.0 \mathrm{~mm}$ AP from bregma, $\pm 1.5 \mathrm{~mm} \mathrm{~L},-1.3$ to $-1 \mathrm{~mm}$ DV from the dura) using a microinjection pump (KD Scientific). The total volume of virus was ejected in portions over several sites along the dorsoventral axis to achieve optimal coverage of the target region. The pipette was left in place for 3 min after each injection before the craniotomy was sealed and the incision sutured. PV-Cre mice recovered in the animal facility for $>4$ weeks, and Chat-Cre mice for $>5$ weeks, before experiments.

\section{Optogenetic experiments}

For excitation of ChR2, square pulses of blue light (450-490 nm, $5 \mathrm{~ms}$ ) from a $100 \mathrm{~W}$ mercury lamp (Nikon C-SHG1) were delivered through the $60 \times$ water-immersion objective of a Nikon E600 microscope equipped with fluorescence filter sets. To set light pulse and train duration, a high-speed shutter (Uniblitz VMM-D1; Vincent Associates) was controlled by a Pulsemaster A300 digital timer (World Precision Instruments), which was triggered by Clampex 10 (Molecular Devices). mCherry was visualized under 557-597 nm light, which did not activate ChR2 in the somata of septal cholinergic cells.

\section{Morphological experiments}

Tissue preparation. Male Sprague Dawley rats $(n=7$; P35-P50) were deeply anesthetized with sodium pentobarbital (150 mg/kg, i.p.) and perfused via the ascending aorta with $4 \%$ paraformaldehyde (PFA) in phosphate buffer (PB) for immunofluorescence, or $3.75 \%$ acrolein in $2 \%$ PFA in PB for electron microscopy (EM). Brains were removed and tissue was postfixed ( $4 \%$ PFA or $1.87 \%$ acrolein $/ 2 \%$ PFA in PB) overnight at $4^{\circ} \mathrm{C}$. Coronal sections ( $40 \mu \mathrm{m}$ thick) were cut on a vibratome (Leica) in chilled $\mathrm{PB}$, and then treated with $1 \%$ sodium borohydride in $0.1 \mathrm{M} \mathrm{PB}$ for $30 \mathrm{~min}$ and permeabilized with Triton $\mathrm{X}$ for immunofluorescence or freeze-thawed for EM. Sections were rinsed in PB followed by $0.02 \mathrm{M}$ KPBS for immunofluorescence or Tris-buffered saline (TS), pH 7.6 (for EM), and blocked (normal goat serum and normal horse serum, 1:100), and $0.03 \%$ Triton $\mathrm{X}$ in KPBS for $1 \mathrm{~h}$ at room temperature for immuno- fluorescence labeling, or in $0.5 \%$ bovine serum albumin (BSA) in TS for 30 min for EM.

Antisera. Antibody dilutions, sources, and related references are shown in Table 1. We used a well documented antibody (Ernst et al., 2009), which has been validated against the $\mathrm{Ca}_{\mathrm{v}} 3.1$ knock-out mouse by T. Snutch (personal communication). To confirm antibody specificity, control experiments included slice treatment: (1) without the primary antibody, (2) without the secondary antibody, and (3) for Cav3.1 with the antibody that had been incubated for $2 \mathrm{~h}$ at room temperature with 1 $\mu \mathrm{g}$ of the preimmune peptide (Alomone). Selective immunoresponsivity was not visible after any control treatment.

Immunohistochemistry. After blocking, slices were incubated overnight at room temperature in a mixture of primary antibodies in KPBS. Following incubation, the sections were washed in KPBS (30 min) and incubated for $1 \mathrm{~h}$ in biotinylated anti-rabbit antibody (Vector; 1:500). The slices were rinsed several times in KPBS for 30 min and incubated in 1:400 dilutions of anti-mouse IgM conjugated to Cy5 (Jackson ImmunoResearch), anti-mouse IgG conjugated Texas Red (Vector), and avidin-FITC (Vector) for $1 \mathrm{~h}$ (in the dark). The slices were rinsed again in KPBS, and then mounted in Vectashield with DAPI (Vector).

Analysis of immunofluorescence labeling. Imaging was done on a Nikon microscope (Eclipse 80i) equipped with an OptiGrid structured light device (Qioptiq Imaging Solutions) as part of a Volocity Grid Confocal system (Improvision). FITC was excited at $495 \mathrm{~nm}$ (pseudocolored green), emission at $515 \mathrm{~nm}$; Texas Red (pseudocolored red) was excited at $595 \mathrm{~nm}$, emission at $620 \mathrm{~nm}$; and Cy5 was excited at $645 \mathrm{~nm}$, emission at $705 \mathrm{~nm}$ (pseudocolored blue). $Z$-stacks of individual channels were captured with a monochrome CCD camera (Hamamatsu ORCA ER).

The Volocity software can convert $z$-stack images (obtained at $100 \times$ magnification) into a single $3-\mathrm{D}$ volume ( $8 \mu \mathrm{m}$ thick) that can be optically rotated, and each color channel independently monitored. The image frame size was $1024 \times 1024$ pixels. The $z$-axis step size was $0.2 \mu \mathrm{m}$, the voxel dimension was $0.07 \times 0.07 \times 0.2 \mu \mathrm{m}(x-z$, respectively). Exposure times were set by the Volocity "auto exposure" function. After noise removal (with a $3 \times 3 \times 3$ median filter), the mean background intensity was calculated for each volume. Objects five or more times brighter than the background at least four voxels in size were counted.

Axons displayed Taul or synaptophysin immunoreactivity. Stretches of $>5 \mu \mathrm{m}$ of contiguously stained axon were examined for $\mathrm{Ca}_{\mathrm{v}} 3.1 \mathrm{im}$ munopositivity. When putative $\mathrm{Ca}_{\mathrm{v}} 3.1$ staining was observed, the volume was rotated $360^{\circ}$ around its axes to determine whether or not the staining was in contact with axon within the limits of resolution $(\sim 70$ $\mathrm{nm}$ ). $\mathrm{Ca}_{\mathrm{v}} 3.1$ labeling on PV-axons lengths $>4 \mu \mathrm{m}$, which also contained synaptophysin staining, were analyzed.

Immuno-electron microscopy. For EM localization of $\mathrm{Ca}_{\mathrm{v}} 3.1$ in perisomatic-targeting interneurons, sections were dual labeled for PV and $\mathrm{Ca}_{\mathrm{v}} 3.1$. According to published procedures (cf. Karson et al., 2009), sections were incubated in anti-Ca 3.1 and anti-PV antisera in $0.1 \%$ BSA in TS for $1 \mathrm{~d}$ at room temperature followed by a $2 \mathrm{~d}$ incubation at $4^{\circ} \mathrm{C}$. For PV immunoreactivity, sections were incubated in biotinylated donkeyanti-mouse IgG (Vector) and processed with an $\mathrm{ABC}$ peroxidase tech- 
nique. For $\mathrm{Ca}_{\mathrm{v}} 3.1$ labeling, sections were rinsed in TS and incubated in goat anti-rabbit IgG conjugated to $1 \mathrm{~nm}$ gold particles (1:50; Electron Microscopy Sciences) in $0.08 \%$ BSA and $0.01 \%$ gelatin in $0.01 \mathrm{M} \mathrm{PBS,} \mathrm{pH}$ 7.4 , at room temperature for $2 \mathrm{~h}$. Sections were rinsed in PBS, postfixed in $2 \%$ glutaraldehyde in PBS for $10 \mathrm{~min}$, and rinsed in PBS followed by $0.2 \mathrm{~m}$ sodium citrate buffer, $\mathrm{pH}$ 7.4. The conjugated gold particles were enhanced by treatment with silver solution (IntenSE; GE Healthcare) for $10 \mathrm{~min}$. For confirmation, the labeling was also performed with $\mathrm{Ca}_{\mathrm{v}} 3.1$ labeled with immunoperoxidase and PV labeled with immunogold.

Sections were postfixed for $1 \mathrm{~h}$ in $2 \%$ osmium tetroxide, dehydrated through alcohols and propylene oxide, and embedded between two sheets of plastic in EMbed 812 (EMS). Seventy-nanometer-thick sections were cut on an ultratome (Ultracut; Leica) and counterstained with uranyl acetate and Reynold's lead citrate. Images were obtained with a FEI Tecnai Biotwin transmission electron microscope and corrected for brightness and contrast with Adobe Photoshop CS4 (Adobe Systems).

Analysis of EM data. Tissue from the pyramidal cell layers of three animals was thin sectioned, and EM images from the tissue surface were analyzed. Profiles were considered to be double labeled if they contained electron-dense, peroxidase reaction precipitate and one or more gold particle. All profiles dual labeled for both PV and $\mathrm{Ca}_{\mathrm{v}} 3.1$ were photographed and classified as somata, dendrites, spines, axons, or terminals (excitatory or inhibitory) using morphological criteria (Peters et al., 1991).

\section{Statistical analysis}

Statistical analyses performed with SigmaPlot 8.0 or SigmaStat 3.0. Data are given as mean \pm SEM. Two-tailed paired $t$ tests or ANOVA were used; significance levels are indicated.

\section{Results}

\section{Focal ACh application causes bursts of mIPSCs in pyramidal} cells

We first asked whether focal microiontophoretic ACh application could be used to probe the mechanisms of regulation of GABA release from perisomatic-targeting interneurons in CA1. The highly $\mathrm{Ca}^{2+}$-permeable $\alpha 7$ nAChRs are extensively expressed in somatodendritic regions of many CA1 interneurons (Khiroug et al., 2003) and on glutamatergic axon terminals (Sharma and Vijayaraghavan, 2003; Sharma et al., 2008); however, it is not known which nAChRs are present on the perisomatic-targeting interneuron terminals. To investigate this question, we used focal microiontophoresis (0.5-1.5 $\mathrm{s}$ pulses) to apply ACh to GABAergic axons on or near pyramidal cell somata. Focal ACh evoked transient barrages of inward postsynaptic currents (Fig. $1 A$, black trace) that were resistant to NBQX $(10 \mu \mathrm{M})$, APV $(50 \mu \mathrm{M})$, and atropine $(2 \mu \mathrm{M})$ (Fig. $2 C)$, but were abolished by gabazine (Figs. $1 A$, blue trace; $2 C$ ). Reversed iontophoretic pulses (Fig. $1 A$ ) were ineffective. The results imply that ACh induced the release of GABA by activating nAChRs. NBQX, APV, and atropine were present in all subsequent experiments.

ACh-evoked GABA release had an initial phase with many large ( $>50 \mathrm{pA}$ ) IPSCs, and a later phase that continued briefly after the end of the pulse and comprised summated smallamplitude currents (Fig. 1A, black trace). TTX eliminated the initial phase (Fig. $1 A$, red trace) but had no effect on the mIPSCs in the later phase. Thus, TTX delayed the onset latency and timeto-peak of the IPSC responses (Fig. $1 B$ ) but left their decay kinetics unaltered.

The TTX-resistant component of ACh-induced GABA responses accounted for $62.8 \pm 5.3 \%$ of the total charge induced $(n=21)$. If its magnitude was $>15 \mathrm{pC}$, the TTX-resistant response was considered a "burst" of mIPSCs. Because of extensive overlap of mIPSCs, the responses were quantified by integration of the area under the burst envelopes. Bursts were stable for $>1.5$ $\mathrm{h}$ when evoked at 1 or 1.5 min intervals (Fig. $1 A$, inset). mIPSC bursts were observed in 161 cells (i.e., 56\%) of the 288 pyramidal cells tested. In the remainder, the ACh response was either absent or fully blocked by TTX. nAChR responses per se from CA1 pyramidal cells were not observed. TTX was present in the following experiments except as noted.

\section{Location of the nAChRs on GABAergic nerve terminals}

The occurrence of mIPSC bursts in the presence of TTX suggests that ACh acts relatively near the GABA release sites. The restricted spatial extent of the focal microiontophoretic ACh application was confirmed by the following: (1) withdrawal of the iontophoretic pipette by $\sim 50 \mu \mathrm{m}$, which abolished the mIPSC burst (Fig. 1C2) (cf. Karson et al., 2009); and (2) imaging the effective area of influence with intrinsic flavoprotein fluorescence (Shibuki et al., 2003), which revealed a confined zone of influence (Fig. 1C,D). Autofluorescence of mitochondrial flavoproteins represents the level of cellular energy metabolism. It is increased by neurotransmitter activation and hence indicates the effective spatial spread of applied ACh. In TTX, a $0.5 \mathrm{~s}$ ACh application elevated tissue fluorescence in a roughly circular area with a radius of $\sim 50 \mu \mathrm{m}$, and a radius of high concentration $(\geq 80 \%$ of peak) of $\sim 10 \mu \mathrm{m}$ (Fig. 1C). With a $1.5 \mathrm{~s}$ ACh pulse, the maximal radius was $\sim 75 \mu \mathrm{m}$ and the high concentration radius $\sim 20 \mu \mathrm{m}$ (Fig. $1 D$ ). The signals were nearly abolished by the nonselective nAChR antagonist mecamylamine $(10 \mu \mathrm{M})$ (Fig. $1 D)$. Thus, focal ACh microiontophoresis only activated nAChRs in stratum (s.) pyramidale near the synaptic or perisynaptic regions of the axons.

\section{$\alpha 3 \beta 4 \mathrm{nAChRs}$ are the primary triggers of ACh-evoked mIPSC bursts}

ACh-evoked mIPSC burst amplitudes were greatly reduced by bath application of a desensitizing concentration, $20 \mu \mathrm{M}$, of nicotine (to $27.7 \pm 8.8 \%$ of baseline, $p<0.05, n=5$; responses recovered to $82.0 \pm 13 \%$ of control with 10 min of washing; n.s., $n=3$; Fig. $2 A, C$ ), confirming that nAChRs trigger them. Several pharmacological results are summarized in Figure 2C. Mecamylamine $(10 \mu \mathrm{M})$ also reduced the ACh-induced bursts (to $17.8 \pm$ $2.8 \%$ of baseline; $p<0.01 ; n=11)$. Dihydro- $\beta$-erythroidine (DH $\beta \mathrm{E})(10 \mu \mathrm{M})$, an antagonist of $\alpha 4$ - or $\alpha 6$-containing nAChRs and $\alpha 3 \beta 2 \mathrm{nAChRs}$ (Harvey and Luetje, 1996), had no effect ( $p>$ $0.05 ; n=10)$. The selective $\alpha 7 \mathrm{nAChR}$ antagonist methyllycaconitine (MLA) at $50 \mathrm{~nm}$ reduced the mIPSC bursts, but by only $\sim 15 \%$ (to $86.6 \pm 5.4 \%$ of baseline; $p<0.05 ; n=8$ ) and the positive $\alpha 7 \mathrm{nAChR}$ allosteric modulator, $N$-(5-chloro-2,4-dimethoxyphenyl)- $N^{\prime}$-(5-methyl-3-isoxazolyl)urea (PNU-120596), 1 $\mu \mathrm{M}$, enhanced them (to $169.1 \pm 20.8 \%$ of baseline; $p<0.05 ; n=7$ ), suggesting that $\alpha 7 \mathrm{nAChRs}$ play a modest role. (Asymmetry between the $\alpha 7 \mathrm{nAChR}$ antagonist and agonist effects is expected, because release is steeply related to $\mathrm{Ca}^{2+}$ influx, which will be increased by PNU-120596, even if $\alpha 7 \mathrm{nAChRs}$ are present at a relatively low density.) In contrast, the $\alpha 3 \beta 4$-nAChR-specific antagonist, $\alpha$-conotoxin AuIB (AuIB) (Luo et al., 1998), $2 \mu \mathrm{M}$, reversibly reduced the mIPSC burst by $\sim 80 \%$ (to $21.2 \pm 3.7 \%$ of baseline; $p<0.01, n=7$; recovery to $84.7 \pm 13.9 \%$ with washing; n.s., $n=7$; Fig. $2 B, C$ ). Adding $50 \mathrm{~nm}$ MLA to AuIB essentially abolished the remaining current (to $7.6 \pm 2.0 \%$ of control; $p<0.05 ; n=6$; Fig. $2 B, C$ ). In the presence of MLA, AuIB also blocked the TTX-sensitive IPSCs (to $12.9 \pm 1.6 \%$ of baseline; $p<0.01 ; n=4$; Fig. $2 D, E$; recovery to $85.5 \pm 9.6 \%$ with washing; n.s.; $n=4$ ), showing that action potential-dependent GABA release was also regulated by $\alpha 3 \beta 4 \mathrm{nAChR}$. Although it appears that the $\mathrm{nAChRs}$ responsible for GABA release 
A
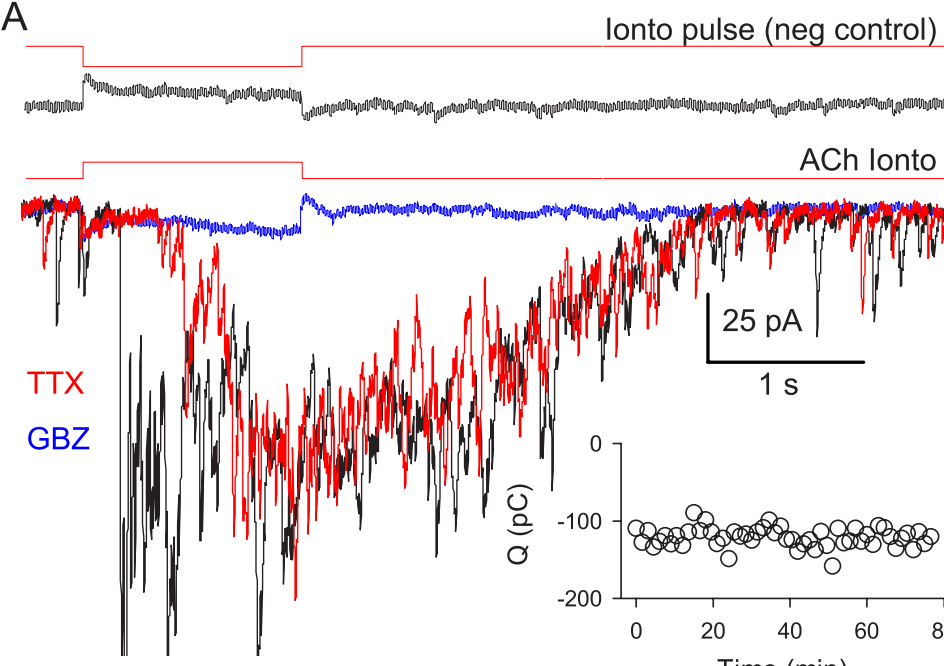

C1
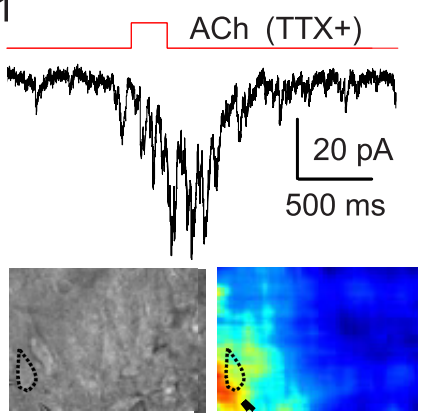

C2
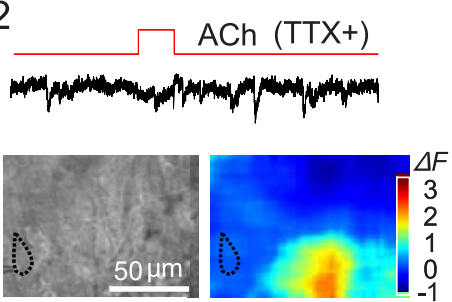

ACh lonto

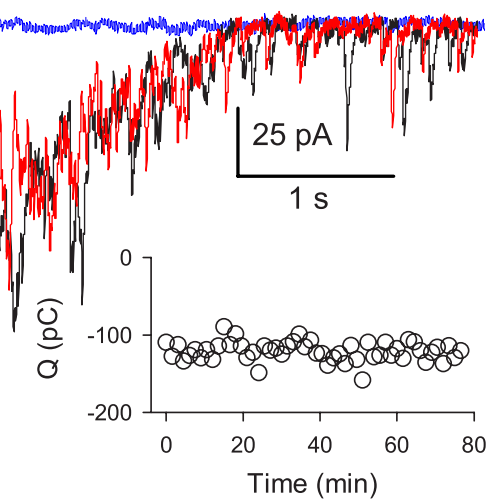

D
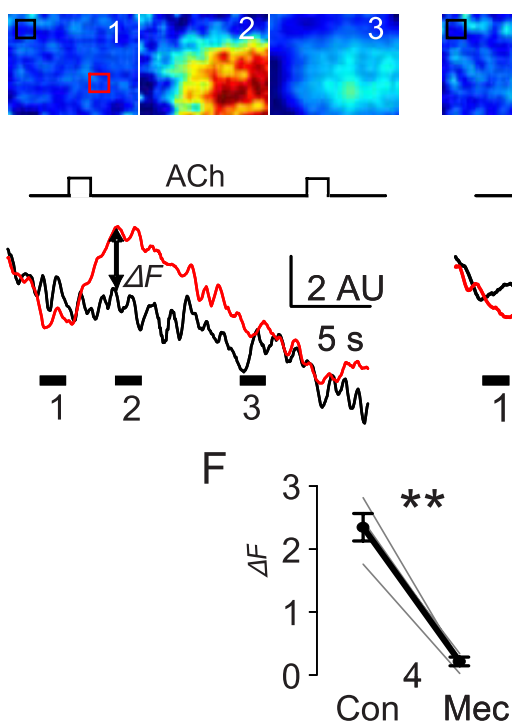
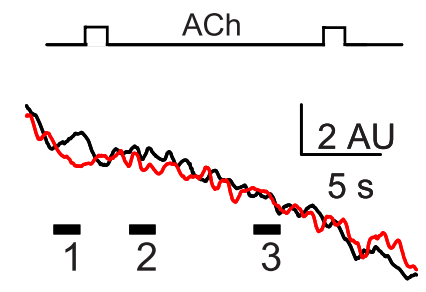

B1
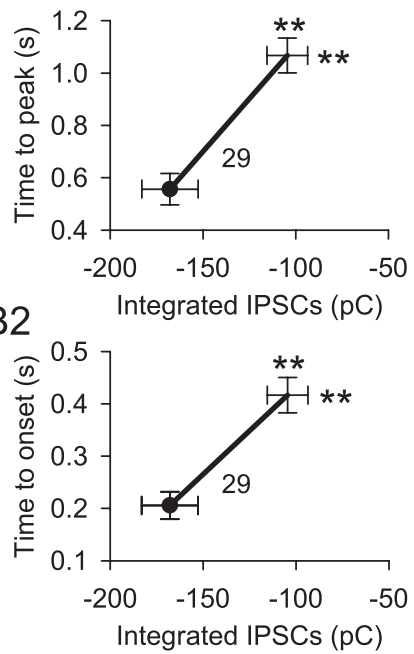

E

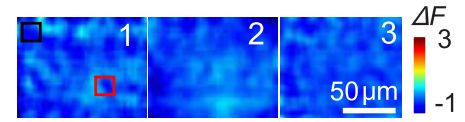

$\mathrm{Mec}$

Figure 1. Local ACh applications to perisomatic-targeting interneuron terminals evokes mIPSC bursts in pyramidal cells. A, Microiontophoretic application of ACh (indicated by red lines above traces) evoked postsynaptic currents in pyramidal cells. The top panel shows the response to an inverted iontophoretic pulse as a negative control. The bottom panel depicts typical responses to ACh in normal saline (black), TTX (red), and $10 \mu \mathrm{m}$ gabazine (blue). The inset illustrates the stability of ACh response in TTX. Changes in time-to-peak (B1) and time-to-onset (B2) of the responses as functions of the magnitudes of the integrated ACh responses (in picocoulombs) before (filled circles) and after (open ends of lines) TTX application (means \pm SEMs). In this and all subsequent figures, the numbers in the figure denote the group sizes. $\boldsymbol{C}, \boldsymbol{D}$, Areas of effective $A C h$ action assessed by local changes of intrinsic flavoprotein fluorescence (see Materials and Methods). All experiments were done in the presence of TTX. C1, ACh delivered close to a recorded pyramidal cell (outlined in dotted black line) induced a burst of mIPSCs and a dramatic increase in flavoprotein fluorescence in a small region (red area) near the cell. (2), Delivery of ACh $50 \mu \mathrm{m}$ away from the same cell as in $\mathbf{C}$ failed to evoke GABA release or a change in intrinsic fluorescence near the cell. The images were averaged from three consecutive trials. ${ }^{* *} p<0.01$. $D$, Images show distribution of fluorescence changes $(\Delta F)$ before, during, and after the $A C h$-induced $F$ peak. The red and black traces below denote the averaged $F$ within the red and white boxes, respectively. $E, \Delta F$ distribution before, during, and after the ACh application in the presence of $10 \mu \mathrm{m}$ Mec. $F$, Group data; Mec blocks ACh-induced flavoprotein $\Delta F$.

are on perisynaptic portions of axons in s. pyramidale, we also checked the possibility that focal ACh application might have activated somatodendritic $\alpha 3 \beta 4 \mathrm{nAChRs}$ by making whole-cell recordings from $24 \mathrm{CA} 1$ interneurons ( 9 in s. radiatum and 15 in s. oriens). However, in the presence of the $\alpha 7 \mathrm{nAChR}$ antagonist, MLA, we did not detect any ACh response $>2 \mathrm{mV}$, consistent with the conclusion that $\alpha 7 \mathrm{nAChRs}$ are principally expressed in the somatodendritic regions of these interneurons (Khiroug et al., 2003). Thus, axonal $\alpha 3 \beta 4$ nAChRs mainly account for the ACh-evoked mIPSC bursts, with a minor fraction due to $\alpha 7 \mathrm{nAChRs}$. This might be significant because the $\mathrm{Ca}^{2+}$ permeability of $\alpha 3 \beta 4 \mathrm{nAChRs}$ accounts for only $\sim 3-4 \%$ of their total conductance (Ragozzino et al., 1998).
ACh-evoked GABA release mainly depends on $\mathrm{Ca}^{2+}$ influx through T-type $\mathrm{Ca}^{2+}$ channels

Elevating extracellular $\mathrm{Ca}^{2+}$ concentration from 2.5 to $5 \mathrm{~mm}$ greatly increased the mIPSC bursts (to $234 \pm 36 \%$; $p<0.01 ; n=$ 7 ), indicating the $\mathrm{ACh}$ effect is $\mathrm{Ca}^{2+}$ dependent. $\mathrm{Ca}^{2+}$ flux through nAChRs is generally not blocked by $\mathrm{Cd}^{2+}$ (Léna and Changeux, 1997; Sharma and Vijayaraghavan, 2003). The AChinduced whole-cell currents of the human neuroblastoma cell line, IMR-32, are primarily mediated by $\alpha 3 \beta 4 \mathrm{nAChRs}$ (Nelson et al., 2001), so we used these cells as a bioassay for $\alpha 3 \beta 4 \mathrm{nAChR}$ mediated effects. ACh was applied by focal microiontophoresis with the same parameters as used in slices. We confirmed that the 

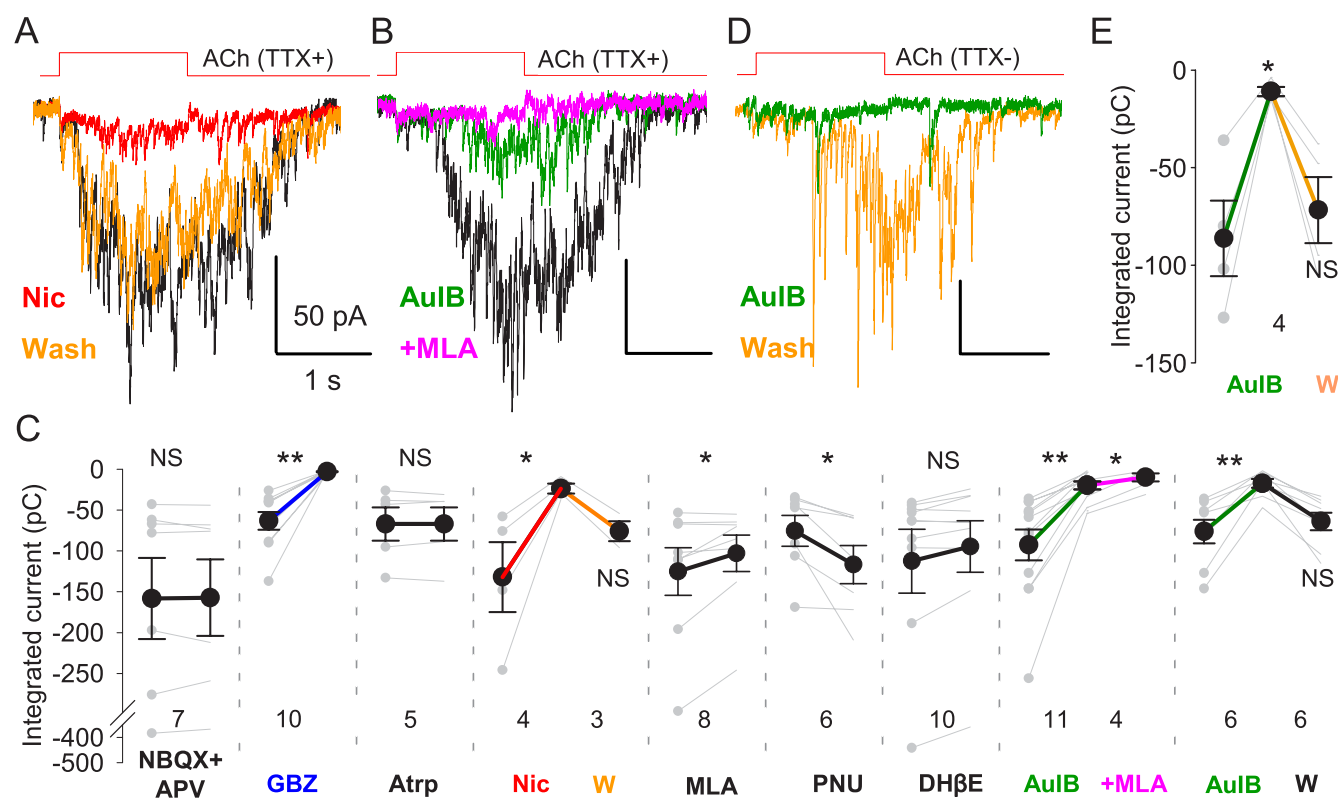

Figure 2. ACh-evoked GABA release depends on activation of $\alpha 3 \beta 4 \mathrm{nAChR}$. $\boldsymbol{A}$, Example of the effects of $10 \mu \mathrm{m}$ nicotine on an ACh-evoked mIPSC burst. $\boldsymbol{B}$, Example of the effects of the selective $\alpha 3 \beta 4$ nAChR blocker, $\alpha$-conotoxin AulB (3 $\mu \mathrm{M}$ ), and subsequent addition of the $\alpha 7 \mathrm{nAChR}$ blocker MLA (50 nM) on an ACh-evoked mIPSC burst. C, Pooled data showing effects of various drugs on integrated ACh-induced mIPSC bursts. D, Example of the effect of AulB (3 $\mu \mathrm{m})$ on an ACh-evoked IPSC burst in the absence of TTX. E, Pooled data showing the reversible blockade of ACh-induced responses by AulB. ${ }^{*} p<0.05,{ }^{* *} p<0.01$.

IMR-32 currents were markedly reduced by the $\alpha 3 \beta 4 \mathrm{nAChR}$ antagonist AuIB (from $229 \pm 47 \mathrm{pA}$ to $36 \pm 11 \mathrm{pA} ; n=5$ cells, $p<0.01) \mathrm{Cd}^{2+}$ reportedly does not affect $\alpha 3 \beta 4 \mathrm{nAChR}$ currents in IMR-32 cells (Donnelly-Roberts et al., 1995), and we confirmed that $\mathrm{Cd}^{2+}(200 \mu \mathrm{M})$ had no significant effect on the IMR-32 cell current in our hands (mean reduction to $93.2 \pm$ $5.7 \%$; n.s.; $n=8$ ). Nevertheless, in slices, $200 \mu \mathrm{M} \mathrm{Cd}^{2+}$ reversibly reduced the ACh-induced mIPSC bursts to $55.5 \pm 3.3 \%$ of baseline $(n=12, p<0.01$; recovery to $102 \pm 20 \%$, n.s., $n=5$, with washing), indicating that VGCCs are significantly involved. Notably, however, the specific toxin blockers of HVA channels typically associated with transmitter release- $\omega$-ConoTX GVIA (500 nM), $\omega$-AgaTX IVA (300 nM), or SNX 482 (100 nM), for N-, $\mathrm{P} / \mathrm{Q}-$, and R-type $\mathrm{Ca}^{2+}$ channels, respectively-did not affect the ACh-induced mIPSC bursts (Fig. $3 F$; all $p>0.05$; $n=4-5$ experiments for each toxin).

Nifedipine $(10 \mu \mathrm{M})$, an L-type $\left(\mathrm{Ca}_{\mathrm{v}} 1\right) \mathrm{Ca}^{2+}$ channel blocker, slightly reduced ACh-induced burst (to $77.0 \pm 6.5 \%$ of baseline; $p<0.05 ; n=13)$, but the selective L-type $\mathrm{Ca}^{2+}$ channel agonists Bay K $8644(1 \mu \mathrm{M} ; n=5)$ and FPL 64176 (5 $\mu \mathrm{M} ; n=8)$ had no effect (Fig. 3F; both $p>0.05 ; n=5$ ) despite increasing whole-cell $\mathrm{Ca}^{2+}$ currents in control experiments. As this casts doubt on a role for L-type $\mathrm{Ca}^{2+}$ channels, we tested the remaining possibility that T-type $\mathrm{Ca}^{2+}$ channels were activated during the ACh responses. The T-type $\mathrm{Ca}^{2+}$ channel blocker mibefradil, $5 \mu \mathrm{M}$, reduced the ACh response (Fig. $3 A, D$; to $42.6 \pm 5.0 \%$ of the total charge in nifedipine; $p<0.01 ; n=11)$. At the concentration of 50 $\mu \mathrm{M}, \mathrm{Ni}^{2+}$ blocks $\mathrm{Ca}_{\mathrm{v}} 2.3$ (R-type $\mathrm{Ca}^{2+}$ channels) and $\mathrm{Ca}_{\mathrm{v}} 3.2$-type T-type $\mathrm{Ca}^{2+}$ channels (Catterall et al., 2005) but did not affect the mIPSC burst ( $106.5 \pm 4.6 \% ; p>0.05 ; n=5)$, while at $100 \mu \mathrm{M}$, a concentration that depresses T-type $\mathrm{Ca}^{2+}$ currents mediated by $\mathrm{Ca}_{\mathrm{v}} 3.1$ and $\mathrm{Ca}_{\mathrm{v}} 3.3$ isoforms (Catterall et al., 2005), $\mathrm{Ni}^{2+}$ reversibly suppressed mIPSC bursts (to $64.7 \pm 5.7 \%$ of baseline, $p<$ $0.01, n=12$; recovery to $100 \pm 37.1 \%$, n.s., $n=5$, with washing). ACh-induced currents in IMR-32 cells were resistant to $\mathrm{Ni}^{2+}$, $100 \mu \mathrm{M}$ (to $100.7 \pm 3.0 \%$; n.s.; $n=4$ ), and mibefradil (to $94.2 \pm$
$4.6 \%$; n.s.; $n=7$ ), indicating that the $\alpha 3 \beta 4 \mathrm{nAChRs}$ are unaffected by these treatments as well.

Despite their efficacy in inhibiting the ACh-induced mIPSC bursts, mibefradil and low concentrations of $\mathrm{Ni}^{2+}$ are only relatively selective for T-type $\mathrm{Ca}^{2+}$ channels; therefore, we tested the selective T-channel antagonist, TTA-P2 (Shipe et al., 2008; Uebele et al., 2009; Dreyfus et al., 2010) at $3 \mu \mathrm{M}$, and found that it too reduced the ACh response (Fig. $3 B, D$; to $55.5 \pm 8.3 \%$ of baseline, $p<0.01, n=6)$. TTA-P2 did not affect the $\alpha 3 \beta 4$ nAChR currents in IMR-32 cells (to $98.4 \pm 2.4 \%$ of baseline; n.s.; $n=5$ ), supporting the interpretation that the TTA-P2 reduction of the ACh-induced GABA release in slices is mediated by its inhibition of T-type $\mathrm{Ca}^{2+}$ channels.

T-type $\mathrm{Ca}^{2+}$ channels are activated by small depolarizations from negative membrane potentials and inactivate at relatively negative potentials (Catterall et al., 2005). If the $\alpha 3 \beta 4 \mathrm{nAChR}$ mediated response depends on T-type $\mathrm{Ca}^{2+}$ channels, it should be highly voltage dependent. To test this prediction, we changed the extracellular $\mathrm{K}^{+}$concentration $\left(\left[\mathrm{K}^{+}\right]_{\mathrm{o}}\right)$ from the normal 3 $\mathrm{mm}$ to 1 or $6 \mathrm{~mm}$ while recording from interneurons near the $\mathrm{s}$. pyramidale/s. oriens border in the presence of TTX. It is not feasible to measure the membrane potential of the interneuronal synaptic terminals, where the T-type $\mathrm{Ca}^{2+}$ channels may be located. Therefore, to confirm the ability of changes in $[\mathrm{K}]_{\mathrm{o}}$ to alter neuronal properties, we used the interneuron soma as a surrogate and found that, as expected, membrane potentials were hyperpolarized (by $3.9 \pm 0.4 \mathrm{mV}$ ) or depolarized (by $7.8 \pm 0.9 \mathrm{mV}$ ), by 1 and $6 \mathrm{mM}[\mathrm{K}]_{\mathrm{o}}$, respectively $(n=6)$. Assuming that the interneuron terminals were similarly affected, we tested the ACh-evoked mIPSC bursts and observed they were increased in $1 \mathrm{~mm}\left[\mathrm{~K}^{+}\right]_{\mathrm{o}}$ and decreased in $6 \mathrm{~mm}\left[\mathrm{~K}^{+}\right]_{\mathrm{o}}$ (Fig. $3 C$,E; both $p<0.05 ; n=8$ ). The results suggest that presynaptic GABAergic terminals were hyperpolarized or depolarized correspondingly and are consistent with the hypothesis that T-type $\mathrm{Ca}^{2+}$ channels played a role in the GABA release process. Although T-type $\mathrm{Ca}^{2+}$ channels are subject to voltage-dependent inactivation, they were apparently 
A

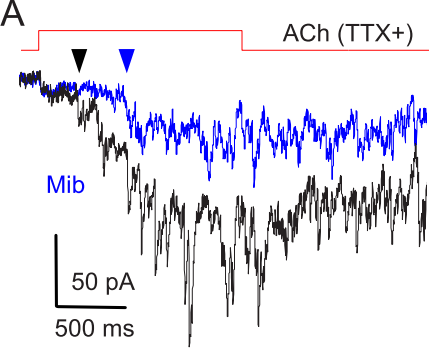

D

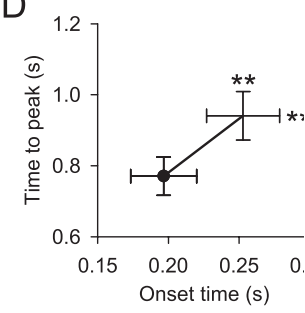

F

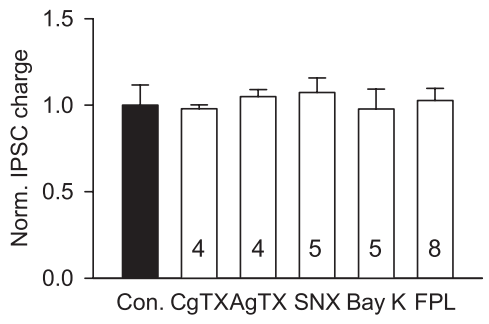

B

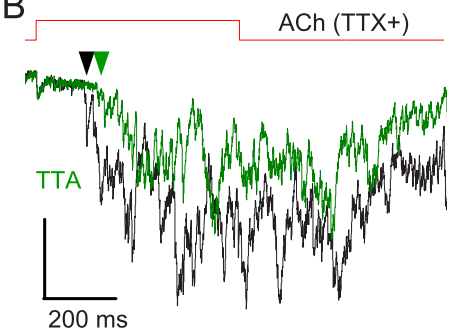

E
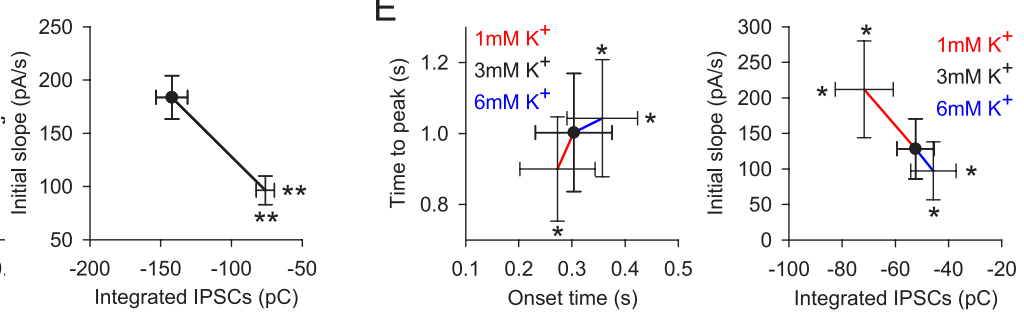

G
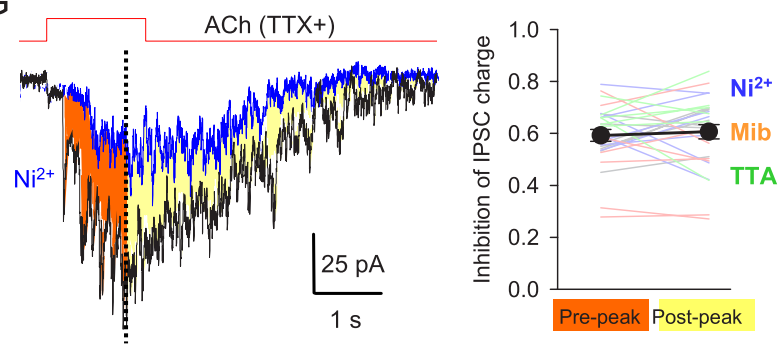

$\mathrm{H} 1$

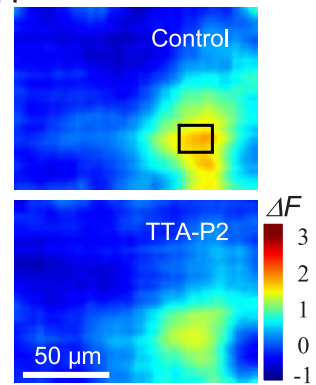

$\mathrm{H} 2$

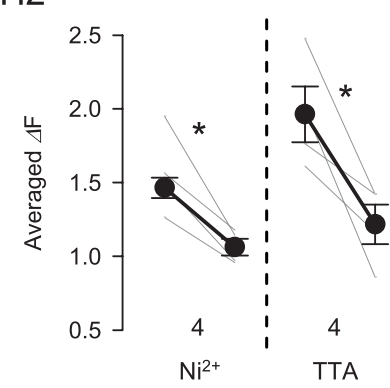

$\mathrm{H} 3$

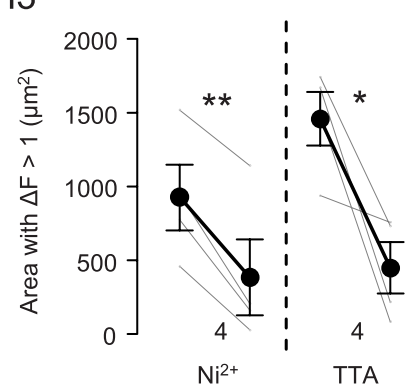

Figure 3. ACh-evoked GABA release depends on opening of T-type $\mathrm{Ca}^{2+}$ channels. $A, B, A C h$-evoked mIPSC bursts in the presence of mibefradil $\left(5 \mu \mathrm{M}\right.$, blue) $(\boldsymbol{A})$ or a specific T-type $C \mathrm{a}^{2+}$ channel antagonist, TTA-P2 (3 $\mu \mathrm{M}$, green) (B). T-type $\mathrm{Ca}^{2+}$ channel blockade by $\mathrm{Ni}^{2+}{ }^{2+}$, mibefradil, and TTA-P2 reduced the total charge, delayed the onset and time-to-peak and decreased the initial rising slope of ACh-evoked mIPSC bursts (D). C, ACh-evoked responses in presence of different $\left[\mathrm{K}^{+}\right]_{0}$ concentrations. Baselines were adjusted to make comparisons easier. $\boldsymbol{E}$, Reducing $\left[\mathrm{K}^{+}\right]_{0}$ increased the total charge, accelerated the time-to-peak and enhanced the initial rising slope of ACh-evoked mIPSC burst. Elevating $\left[\mathrm{K}^{+}\right]_{0}$ had the opposite effects. $\boldsymbol{F}$, ACh evoked mIPSC bursts were insensitive to antagonists of $\mathrm{Ca}_{\mathrm{v}} 2$ channels (CgTX, $\omega$-conotoxin GVIA; AgTX, $\omega$-agatoxin IVA; SNX, SNX 482) or agonists of Ca 1 channels (Bay K, Bay K8644; FPL, FPL 64176). G, T-type Ca ${ }^{2+}$ channel blockade suppressed ACh-evoked responses before (filled red area) or after (filled yellow area) the peak ACh-induced response to the same extent. Group data ( $n=23)$ for experiments as in $\mathbf{G}$ (left). $\boldsymbol{H} \mathbf{1}-\boldsymbol{H 3}$, Flavoprotein fluorescence signals $(\Delta F)$ are blocked by T-type $\mathrm{Ca}^{2+}$ channel antagonists. $\boldsymbol{H 1}$, Image of ACh-induced $\Delta F$ in control condition (top) and in TTA-P2 (bottom). $\boldsymbol{H 2}$, Mean ACh-induced $\Delta F$ changes are reduced by $100 \mu \mathrm{M} \mathrm{Ni}{ }^{2+}$ or $3 \mu \mathrm{M}$ TTA. H3, Area of region with $\Delta F>1$ is reduced by $\mathrm{Ni}^{2+}$ or TTA. ${ }^{*} p<0.05 ;{ }^{* *} p<0.01$.

not inactivated by ACh application, as their contribution to the ACh-induced mIPSC burst remained constant throughout the response (Fig. 3G). Finally, T-type $\mathrm{Ca}^{2+}$ channel antagonists suppressed the increase in flavoprotein fluorescence (Fig. $3 H$ ), in agreement with the interpretation that they are activated by $\mathrm{ACh}$ application.

\section{Morphological evidence for $\mathrm{Ca}_{\mathrm{v}} 3.1$ on inhibitory axon terminals}

Together, the physiological and pharmacological data are consistent with the hypothesis that $\mathrm{Ca}^{2+}$ influx through T-type $\mathrm{Ca}^{2+}$ channels triggers a GABA release process that is initiated by activation of $\alpha 3 \beta 4 \mathrm{nAChRs}$. Nevertheless, T-type $\mathrm{Ca}^{2+}$ channels have not generally been observed on terminal or preterminal axons in the mammalian brain (Catterall et al., 2005). We therefore used multifluorescence confocal immunohistochemistry and dual-labeling electron microscopy to test the prediction that T-type $\mathrm{Ca}^{2+}$ channels exist on and near GABAergic axonal release sites.

The $\mathrm{Ca}_{\mathrm{v}} 3.1$ antibody yielded immunoreactivity throughout the hippocampus, as previously reported (McKay et al., 2006; Vinet and Sík, 2006). The specificity of this antibody has been validated (Kim et al., 2001); however, the available $\mathrm{Ca}_{\mathrm{v}} 3.3$ antibody yields off-target labeling (Chen et al., 2007) and was not tested. At $20 \times$ magnification, $\mathrm{Ca}_{\mathrm{v}} 3.1$ immunoreactivity was strongest in CA1 s. pyramidale, with intense labeling of pyramidal cell somata and proximal dendrites (Fig. 4A1). Interneuronal somata scattered throughout s. pyramidale, s. radiatum, and s. 

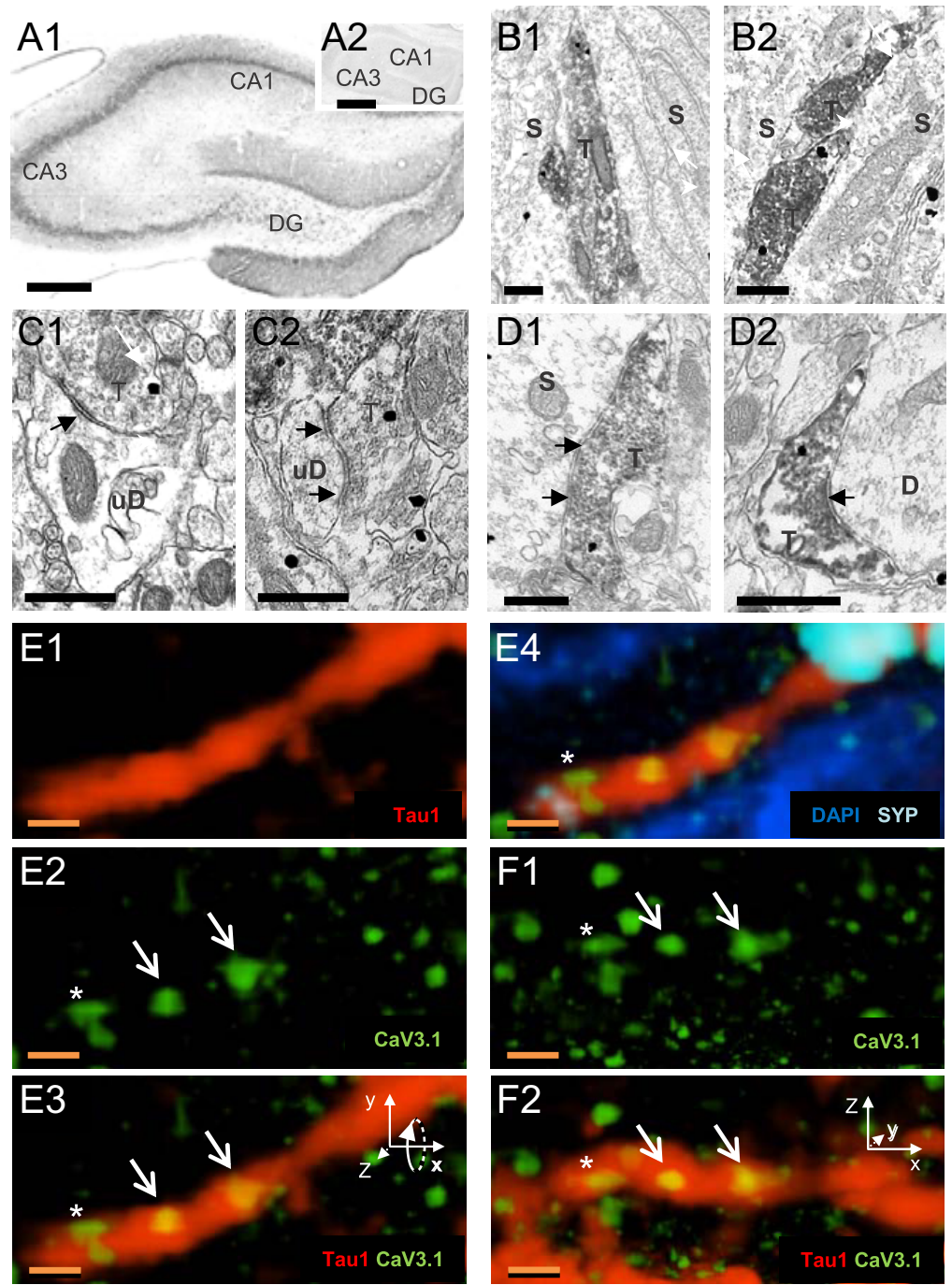

Figure 4. $\quad \mathrm{Ca}_{\mathrm{v}} 3.1$ channels are expressed on PV axons in CA1 s. pyramidale. A1, Hippocampal $\mathrm{Ca}_{v} 3.1$ immunostaining $(4 \times$ magnification). $\boldsymbol{A 2}, \mathrm{Ca}_{\mathrm{v}} 3.1$ immunolabeling is blocked by absorption in preimmune peptide. Scale bars, $200 \mu \mathrm{m}$. $\boldsymbol{B}-\boldsymbol{D}$, Electron micrographs of PV (peroxidase)- and Ca 3.1 (immunogold)-labeled profiles in s. pyramidale. S, Soma, D, dendrite, T, terminal Scale bars, $500 \mathrm{~nm}$. B1, B2, Double-labeled profiles appose pyramidal somata. C1, C2, Ca 3.1 -labeled terminals make synaptic contacts (arrows) on dendrites. D1, D2, Double-labeled terminals make synaptic contacts (arrows) on pyramidal cell profiles. E1-E3, A Tau1-labeled axon (red) contains Ca 3.1-immunoreactive puncta (green). Two large puncta are within the structure (E2, E3, arrows), and one is in close apposition $\left(^{*}\right)$. E4, The Tau1-labeled axon also contains synaptophysin (SYP) immunoreactivity (light blue). The $\mathrm{Ca}_{\mathrm{v}} 3.1$ puncta not contained in the Tau1-labeled axon may be in neighboring somata (nuclei stained with DAPI, dark blue). $\boldsymbol{F 1}, \boldsymbol{F 2}$, Same as $\boldsymbol{E 2}$ and $\boldsymbol{E 3}$, rotated into the plane by $90^{\circ}$ (note rotation of inset $x-z$ coordinates). (a $3.1-$ immunoreactive puncta were within the axon even under rotation. Scale bars: $\boldsymbol{E}, \boldsymbol{F}, 1 \mu \mathrm{m}$.

oriens also showed $\mathrm{Ca}_{\mathrm{v}} 3.1$ immunoreactivity. No labeling was observed in slices treated with antibody plus preimmune peptide (compare Fig. 4A2).

\section{Ultrastructural evidence of presynaptic $\mathrm{Ca}_{\mathrm{v}} 3.1$ expression}

Because CCK interneurons predominantly express $\alpha 7$ nAChRs (Morales et al., 2008), the large, non- $\alpha 7$ nAChR-mediated responses probably originate from the non-CCK-perisomatic cells that express PV, and we therefore focused on this possibility. Slices were stained for PV and $\mathrm{Ca}_{\mathrm{v}} 3.1$ (alternating immunoperioxidase and immunogold labeling for each antibody), and ultrathin sections of CA1 made. Within putative pyramidal cell and interneuronal somata and dendrites, $\mathrm{Ca}_{\mathrm{v}} 3$.1-like immunoreactivity was visible throughout the cytoplasm (Fig. $4 B-D$ ) of PV-labeled and unlabeled presynaptic axons $(n=191)$ and apparent (see Ma- terials and Methods) inhibitory terminals $(n=254)$. Approximately $16 \%$ of all axons and $\sim 25 \%$ of all putative inhibitory terminals had $\mathrm{Ca}_{\mathrm{v}} 3.1$ immunogold labeling. Of the immunoperoxidase-PV-labeled processes, $13 \%$ of the axons and $23 \%$ of the terminals also labeled for $\mathrm{Ca}_{\mathrm{v}} 3.1$ immunogold. Dual (PV plus $\mathrm{Ca}_{\mathrm{v}} 3.1$ )-labeled terminals made contacts primarily on putative pyramidal cell somata or dendrites (Fig. 4C,D; Table 2). In the reverse configuration, when $\mathrm{Ca}_{\mathrm{v}} 3.1$ was labeled with immunoperoxidase and PV was labeled with immunogold, both PV-labeled and -unlabeled axons $(n=160)$ and inhibitory terminals $(n=$ 282) showed $\mathrm{Ca}_{\mathrm{v}} 3.1$-like immunoreactivity. Of the immunogold-PV-labeled processes, $46 \%$ of the axons and $23 \%$ of the terminals expressed $\mathrm{Ca}_{\mathrm{v}} 3.1$-like immunoreactivity (Table 2). None of the asymmetrical, apparently excitatory terminals $(n=647)$ observed had $\mathrm{Ca}_{\mathrm{v}} 3.1$ immunolabeling.

As others have reported (Kovács et al., 2010; Parajuli et al., 2010), we find $\mathrm{Ca}_{\mathrm{v}} 3.1$ immunolabeling predominantly on the cytoplasmic side of cell membranes. In the inhibitory terminals $(n=62)$ and axons $(n=31)$ containing immunogold-labeled $\mathrm{Ca}_{\mathrm{v}} 3.1$, there was one $\mathrm{Ca}_{\mathrm{v}} 3.1$ gold particle per $1.0 \pm 0.47 \mu \mathrm{m}$ length of axon. Within an axon having a visible terminal $(n=$ $15)$, the mean distance between an axonal $\mathrm{Ca}_{\mathrm{v}} 3.1$ immunogold particle and the closest terminal border was $444.9 \pm 72.1 \mathrm{~nm}$. Within terminals, $35.5 \%$ ( 44 of 124) of the $\mathrm{Ca}_{\mathrm{v}} 3.1$ immunogold particles were located $\leq 50 \mathrm{~nm}$ from the closest plasma membrane, suggesting that these particles label T-type $\mathrm{Ca}^{2+}$ channels in the plasma membrane, with the remainder associated with internal structures (cf. Parajuli et al., 2010). $\mathrm{Ca}_{\mathrm{v}} 3.1$ labeling was found $266.7 \pm$ $21.7 \mathrm{~nm}$ from the active zone. Thus, as predicted by our hypothesis, $\mathrm{Ca}_{\mathrm{v}} 3.1 \mathrm{im}$ munoreactivity is found in preterminal PV-labeled axons near, although not in, active zones.

\section{Multifluorescence confocal immunohistochemistry}

As a complementary approach, fluorescently labeled antibodies against $\mathrm{Ca}_{\mathrm{v}}$ 3.1, PV, a marker for neuronal axons (Tau1 protein), a presynaptic terminal marker (synaptophysin), and the nuclear marker, DAPI, to identify cell somata, were used. Typically, a given slice was stained with three antibodies plus DAPI, to ensure that axon terminals in CA1 s. pyramidale were proximate to pyramidal cell somata.

At $100 \times$ magnification, $\mathrm{Ca}_{\mathrm{v}} 3.1$ labeling within single cells was diffuse and punctate, with individual puncta being rounded and between 250 and $600 \mathrm{~nm}$ in diameter (365 $\pm 9 \mathrm{~nm} ; n=100)$, often aggregated into variably sized "large puncta" that were found throughout pyramidal cell somata and primary dendrites, and sometimes at somatic edges or the nuclear membrane. $\mathrm{Nu}$ - 


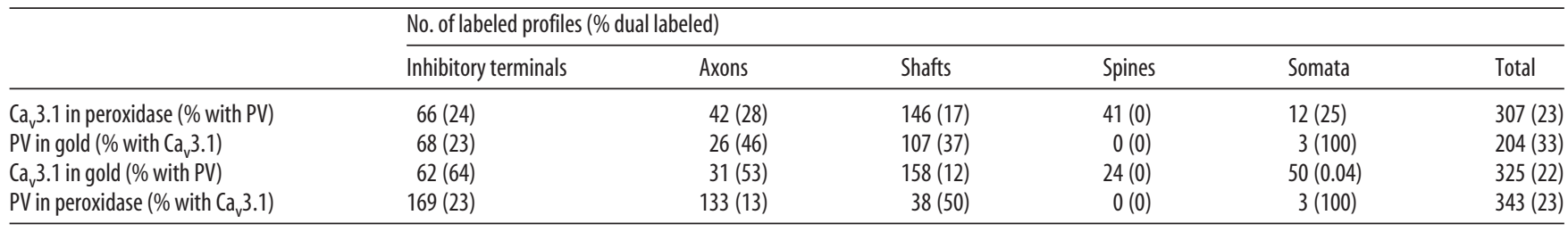

Ultrastructural distribution of observed profiles containing $\mathrm{Ca}_{v} 3.1$ and PV immunoreactivity. Each cell gives the total number of labeled profiles and in parentheses the percentage of these profiles that were double labeled by antibodies to both Ca 3.1 and PV. For example, the cell in the upper left indicates that, with the $\mathrm{Ca}_{v} 3.1$ antibody labeled with peroxidase, 66 inhibitory nerve terminal profiles were found to be labeled, and that $\sim 24 \%$ of these (16) were also labeled with an immunogold-tagged PV antibody. The percentages pertain only to the given table cell and are not to be summed across cells.

merous puncta were also visible in spaces between neighboring somata, consistent with their localization on perisomatictargeting axons. We evaluated 50 randomly selected axon segments labeled with Tau1, synaptophysin, and $\mathrm{Ca}_{\mathrm{v}} 3.1$, within s. pyramidale (Fig. $4 E, F$; data in Table 2). The segments were $\geq 5 \mu \mathrm{m}$ in length $(10.5 \pm 0.22 \mu \mathrm{m})$ and $500-700 \mathrm{~nm}$ in width. Most (29 of 50) contained large $\mathrm{Ca}_{\mathrm{v}} 3.1$ puncta $\left(1.2 \pm 0.37 \mathrm{Ca}_{\mathrm{v}} 3.1\right.$ puncta per $5 \mu \mathrm{m}$ of axonal length), for a total of $79 \mathrm{Ca}_{\mathrm{v}} 3.1$ puncta, 20 of which $(25 \%)$ were also coincident with synaptophysin labeling.

In slices immunolabeled for PV, $\mathrm{Ca}_{\mathrm{v}} 3.1$, and synaptophysin, projections containing PV immunoreactivity that were $\geq 5 \mu \mathrm{m}$ long $(8.5 \pm 0.86 \mu \mathrm{m} ; n=$ 50), 500-700 nm wide, and having synaptophysin immunoreactivity were analyzed. Two-thirds (34 of 50) of these axons contained large $\mathrm{Ca}_{\mathrm{v}} 3.1$ puncta (total, 54 puncta; $1.0 \pm 0.08$ per $5 \mu \mathrm{m}$ axon), of which $6(11 \%)$ were also coincident with synaptophysin labeling. These data are consistent with the interpretation that the $\alpha 3 \beta 4$ nAChR-Ca 3 mechanism is located on PV terminals. Thus, the immunohistochemical data supported predictions that $\mathrm{Ca}_{\mathrm{v}} 3.1$ labeling is colocalized within presynaptic inhibitory interneuron profiles, appropriate for the proposed role of T-type $\mathrm{Ca}^{2+}$ channels in regulating GABA release.

\section{$\mathrm{Ca}^{2+}$ stores and $\mathrm{Ca}^{2+}$-release coupling}

T-type $\mathrm{Ca}^{2+}$ channel antagonists do not fully block nAChRdependent GABA release (Fig. $3 A$ ), prompting the question of whether other factors might also be involved. Liberation of $\mathrm{Ca}^{2+}$ from endoplasmic reticulum stores triggers synaptic transmission at various synapses (Verkhratsky, 2005). To test the possibility that $\mathrm{Ca}^{2+}$-induced release from presynaptic $\mathrm{Ca}^{2+}$ stores (CICR) contributes to the ACh-evoked mIPSC burst, we bathapplied the $\mathrm{Ca}^{2+}$ pump inhibitor thapsigargin (TG) $(10 \mu \mathrm{M})$ and observed that it reduced the mIPSC burst to $54.5 \pm 3.8 \%(n=5)$ of baseline (Fig. $5 A, C$ ). The responses were also reduced by another $\mathrm{Ca}^{2+}$ pump inhibitor, CPA $(20 \mu \mathrm{M})$, to $48.4 \pm 7.5 \%(n=10)$; by ryanodine (Ryn) $(100 \mu \mathrm{M})$ to $49.7 \pm 4.3 \%(n=7$; Fig. $5 B, C)$; and by caffeine (Caf) (10 mM) to $71.8 \pm 4.8 \%, p>0.05, n=11$ (Fig. $5 C$ ), but not by the $\mathrm{IP}_{3} \mathrm{R}$ blocker xestospongin $\mathrm{C}(\mathrm{XeC})(5 \mu \mathrm{M})$ to $97.1 \pm$ $2.4 \%$, n.s. $(n=5$; Fig. $5 C)$. These results suggest that ryanodine-
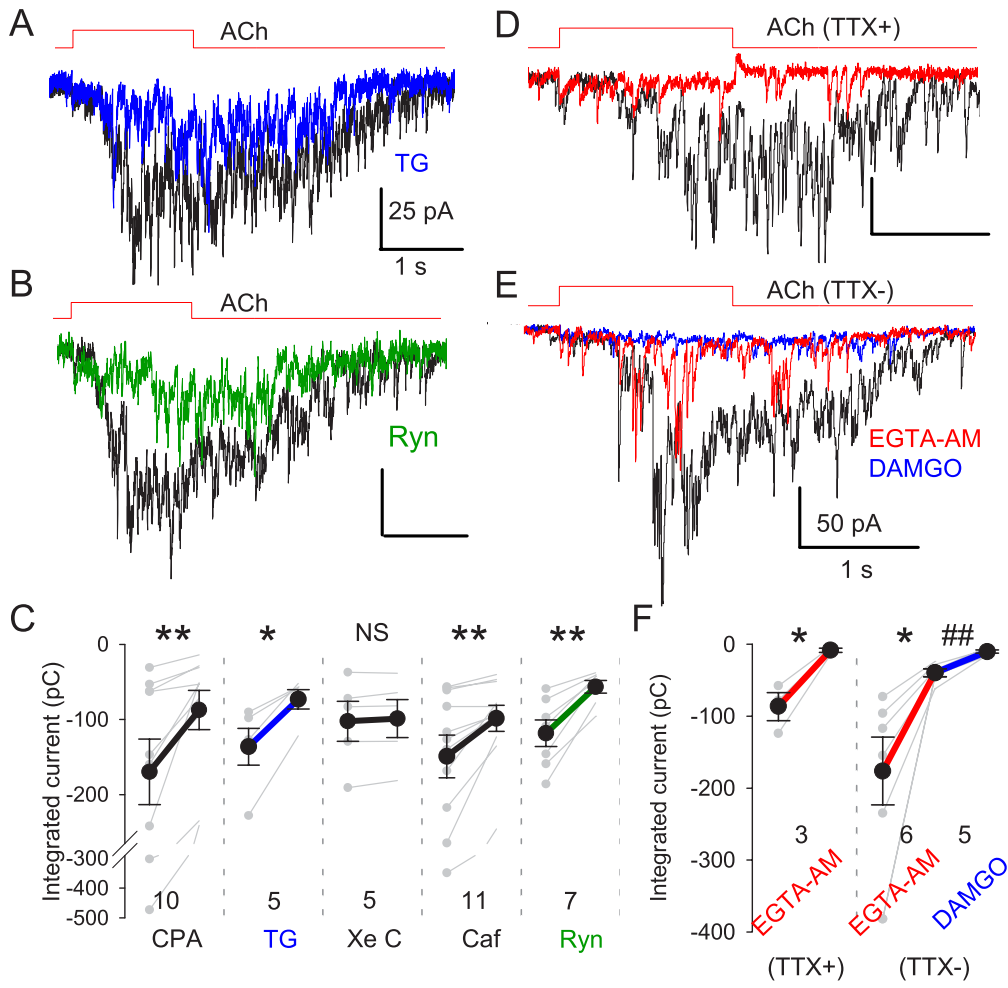

Figure 5. nAChR-mediated mIPSCs are dependent on store $\mathrm{Ca}^{2+}$ and are loosely coupled to $\mathrm{Ca}^{2+}$ increases. MLA (50 nM) was continuously applied in all experiments to isolate non- $\alpha 7 \mathrm{nAChR}$-mediated responses. $A$, Depletion of intracellular $\mathrm{Ca}^{2+}{ }^{2}$ stores by of RyRs by ryanodine (Ryn) (100 $\mu \mathrm{m}$ ) (green trace) reduced ACh-evoked mIPSC bursts. C, Group data for $\mathrm{Ca}^{2+}$ store experiments. D, An ACh-evoked mIPSC burst was fully blocked by bath-applied EGTA-AM (100 $\mu \mathrm{m}$ for $10 \mathrm{~min}$; red trace). E, ACh-induced in the absence of TTX were reduced, but not fully blocked, by EGTA-AM (red trace). The remaining IPS(s were blocked by AMGO $(1 \mu \mathrm{m})$ (blue trace). $\boldsymbol{F}$, Summary of EGTA-AM effects on nAChR-mediated responses. Note that EGTA-AM abolished action potential-independent mIPSC bursts, but not action potential-dependent release, which was abolished by $\mu O R$ activation. ${ }^{*} p<$ $0.05,{ }^{* *} p<0.01,{ }^{\# \#} p<0.01$ for EGTA-AM group.

receptor mediated CICR partially mediates the nAChRinduced GABA release, as is the case for $\mathrm{nAChR}$-induced glutamate release in CA3 (Sharma and Vijayaraghavan, 2003). The onset delay of ACh-induced GABA release (Figs. 1B2, 3D), together with an apparent role for CICR, suggested that the relationship between $\mathrm{Ca}^{2+}$ sources and sensors for $\mathrm{nAChR}$-induced GABA release might not reflect tight coupling between $\mathrm{Ca}^{2+}$ influx and transmitter release. The efficacy of $\mathrm{Ca}^{2+}$ chelators can be used to distinguish between tight and loose coupling between $\mathrm{Ca}^{2+}$ and its effectors (Neher, 1998; Bucurenciu et al., 2008). The membrane-permeant, slow $\mathrm{Ca}^{2+}$ chelator, EGTA-AM, disrupts loosely coupled asynchronous release (Hefft and Jonas, 2005; Daw et al., 2009; Karson et al., 2009), whereas synchronous release is resistant to EGTA-AM (Hefft and Jonas, 2005). We found that the nAChR-induced mIPSC burst was essentially abolished by EGTA-AM (Fig. 5D,F; to $9.1 \pm 2.7 \%$ of baseline; 
A
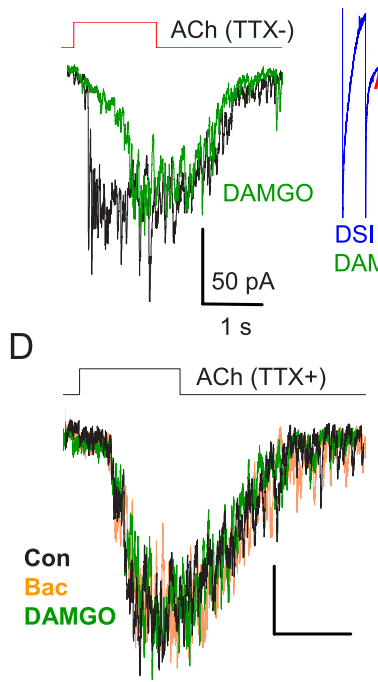

B

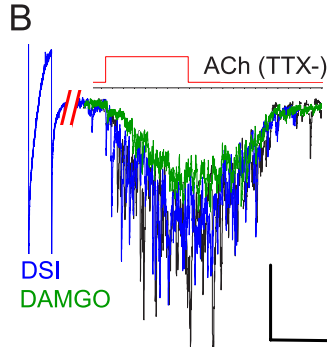

$\mathrm{E}$
C
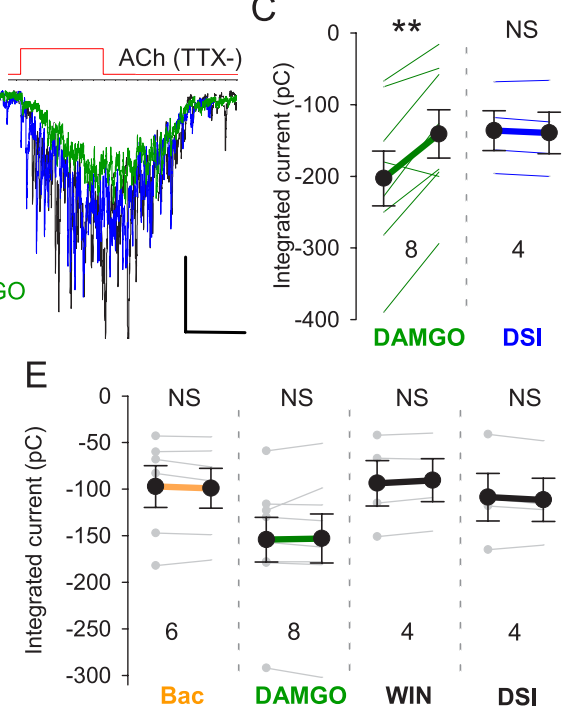

NS

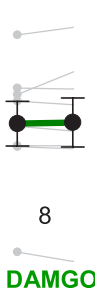

NS

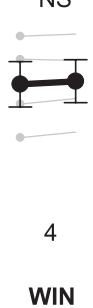

Figure 6. nAChR-induced mIPSC bursts are resistant to GPCR inhibition. $\boldsymbol{A}$, In the absence of TTX, DAMGO (1 $\mu \mathrm{M})$ (green) reduced $A C h$-induced responses, showing that $A C h$-evoked action potential-dependent GABA release can be inhibited by $\mu 0 R$ activation. $B$, Depolarization of postsynaptic pyramidal cells, which releases endocannabinoids and activates presynaptic $\mathrm{B}_{1} \mathrm{Rs}$, had no effect on the $A C$-evoked response (blue). DAMGO still reduced the response (green trace). $C$, Group data from experiments as in $\boldsymbol{A}$ and $\boldsymbol{B}$. $\boldsymbol{D}$, In the presence of TTX, nAChR-induced mIPSC bursts are insensitive to baclofen $(2 \mu \mathrm{M})$, DAMGO $(1 \mu \mathrm{M})$, or WIN $55212-2(2 \mu \mathrm{M})$, agonists of $\mathrm{GABA}_{B} \mathrm{RS}, \mu 0 \mathrm{Rs}$, or $\mathrm{CB}_{1} \mathrm{Rs}$, respectively. Releasing endocannabinoids by a DSI protocol (depolarizing $P\left(\right.$ to $0 \mathrm{mV}$ for $5 \mathrm{~s}$ ) also had no effect. $\boldsymbol{E}$, Group data for experiments as in $\boldsymbol{D}$. ${ }^{* *} p<0.01$.

$p<0.05 ; n=3)$ but that action potential-dependent AChevoked release was not (Fig. $5 E, F$, red trace). This argues that nAChR-induced release is mediated by different mechanisms than action-potential dependent release and is consistent with the hypothesis that several steps may intervene between $\mathrm{ACh}$ action and GABA release.

\section{nAChR-induced mIPSC release is resistant to GPCR inhibition}

HVA-controlled transmitter release is often modulated by presynaptic GPCRs (Wu and Saggau, 1997). T-type- $\mathrm{Ca}^{2+}$ channeldependent release might be regulated differently. GABA release from perisomatic-targeting interneurons can be modulated by $\mathrm{GABA}_{\mathrm{B}} \mathrm{Rs}, \mu \mathrm{ORs}$, and $\mathrm{CB}_{1}$ Rs (Freund, 2003; Freund and Katona, 2007). Activation of these receptors by synthetic agonists WIN 55212-2 ( $\left.\mathrm{CB}_{1} \mathrm{Rs}\right)$, DAMGO ( $\left.\mu \mathrm{ORs}\right)$, baclofen $\left(\mathrm{GABA}_{\mathrm{B}} \mathrm{Rs}\right)$, or endocannabinoid release from pyramidal cells via depolarizationinduced suppression of inhibition (DSI) (Ohno-Shosaku et al., 2001; Wilson and Nicoll, 2001; Alger, 2002) profoundly inhibits normal action-potential-dependent transmission. When EGTA-AM had abolished ACh-evoked quantal release (50 nM MLA present), the remaining action potential-dependent IPSCs (Fig. 5E; $26.5 \pm$ $3.1 \%$ of baseline; $p<0.05 ; n=6$ ) were almost totally eliminated by DAMGO (Fig. $5 E, F$; to $6.0 \pm 1.4 \%$ of baseline; $p<0.01 ; n=5$ ). Indeed, in the absence of TTX, ACh-evoked responses were significantly reduced by DAMGO (to $64.3 \pm 9.3 \%$ of baseline; $p<0.01$; $n=8$; Fig. $6 A-C$ ) but were unaffected by endocannabinoids elicited by a DSI protocol (Fig. $6 B, C$ ) (to $101.8 \pm 1.7 \%$ of baseline; $p>0.05$; $n=4)$. Surprisingly, however, when TTX was present, neither DAMGO, nor baclofen, nor cannabinoids (DSI or the synthetic $\mathrm{CB}_{1} \mathrm{R}$ agonist, WIN 55212-2) suppressed ACh-evoked mIPSC bursts (Fig. $6 D, E$; all $p>0.05$ ), underscoring the differences between T-channel and HVA-mediated neurotransmitter release mechanisms.
NS

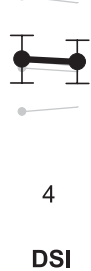

\section{Inhibition of action potential firing}

If the $\alpha 3 \beta 4 \mathrm{nAChR}-\mathrm{T}$-channel-induced GABA release is functionally significant, it should alter the excitability of the postsynaptic cell. We therefore recorded from pyramidal cells in current-clamp mode (TTX absent, atropine present), inducing repetitive action potential firing with long depolarizing current pulses. The long current pulses were delivered every $45 \mathrm{~s}$, and an ACh ejection was timed to end $0.5 \mathrm{~s}$ before the pyramidal cell was depolarized on alternate trials, so that an appropriate negative control action potential train could be compared with every experimental train. This prevented any slow changes in excitability from influencing the results. The ACh-induced burst of GABA release caused a relative hyperpolarization of the pyramidal cell membrane potential and delayed the onset of action potential firing (Fig. 7; mean delay of $1.5 \pm 0.4 s ; n=5$ ). Apart from this delay in firing, ACh did not alter pyramidal cell excitability-the relationship between action potential firing and time of occurrence was not changed (Fig. $7 B$ ). The inhibition of firing was abolished by gabazine (Fig. $7 C$; to $0.04 \pm 0.04 \mathrm{~s} ; p<$ $0.05 ; n=4$ ) or MLA plus mecamylamine (Fig. $7 C$; to $0.16 \pm$ $0.05 s ; p<0.05 ; n=5)$.

\section{Identity of interneurons regulated by the $\alpha 3 \beta 4$ nAChR-T-channel mechanism}

Different classes of perisomatic-targeting interneurons have different functional roles (Freund, 2003; Klausberger et al., 2005; Freund and Katona, 2007); hence it is important to identify the cells affected by the $\alpha 3 \beta 4 \mathrm{nAChR}-\mathrm{Ca}_{\mathrm{v}} 3.1$ mechanism. The lack of specific antibodies against $\alpha 3 \beta 4 \mathrm{nAChRs}$ precludes morphological determination of which terminals carry these receptors. Nevertheless, the marked segregation of inhibitory GPCRs to different perisomatic-targeting interneuron subtypes (Freund, 2003) allows for tentative operational identification. $\mu$ ORs are present on PV cells and absent from CCK cells (Drake and Milner, 2002; Freund and Katona, 2007). Conversely, $\mathrm{CB}_{1} \mathrm{Rs}$ are absent from PV cells, but densely present on CCK terminals (Wilson et al., 2001; Freund and Katona, 2007). The ability of DAMGO to abolish the early, action potential-dependent phase of ACh-induced bursts (compare Figs. 1A, 6A) indicates that focal ACh application affects PV cells, and suggests that the PV terminals are reasonable candidates for the site of $\alpha 3 \beta 4 \mathrm{nAChRs}$. This inference is indirectly supported by the finding that $\mathrm{Ca}_{\mathrm{v}} 3.1$ channels are located on PV axons near synaptic terminals (Fig. $8 A, B)$; nevertheless, we do not have direct evidence that the action potential-dependent and action potential-independent stimulation of GABA release by $\alpha 3 \beta 4 \mathrm{nAChRs}$ originates from the same interneurons.

As a more direct test of the involvement of PV cells, we delivered a gene encoding the light-activated cation channel, channelrhodopsin2 (ChR2) (Zhang et al., 2010) selectively to PV interneurons. This was achieved by injecting a Cre-dependent AAV vector carrying ChR2 fused to the fluorescent marker protein mCherry (AAV-ChR2-mCherry) into hippocampi of PV- 
Cre mice. This resulted in intense expression of ChR2-mCherry in interneurons in or near s. pyramidale, and in apparent axonal processes surrounding pyramidal cell somata (Fig. $8 C$ ), which is consistent with labeling of PV-expressing perisomatic-targeting interneurons. Pulses of blue light ( $2-5 \mathrm{~ms} ; \sim 50 \mu \mathrm{m}$ radius) delivered to these slices near the pyramidal cell in the absence of TTX elicits action potential-dependent IPSCs originating from PV interneurons (Fig. $8 D$, black trace). We then conducted "collision" experiments to determine whether the ACh-induced IPSCs arose from PV axons. ACh application to the terminal regions elicits axonal action potentials and TTX-sensitive IPSCs (Figs. 1A, 5E). The action potentials will propagate antidromically, encountering and annihilating spikes traveling orthodromically in the same axons. Thus, our hypothesis predicts that preceding a light flash by ACh application will reduce the light-evoked IPSCs originating from PV axons, because ACh-induced action potentials would be traveling in the same axons. Atropine, MLA, DH $\beta E$, and the $\mathrm{GABA}_{\mathrm{B}} \mathrm{R}$ antagonist CGP 54626 ([S$\left.\left(R^{\star}, R^{\star}\right)\right]$-[3-[[1-(3,4-dichlorophenyl) ethyl]amino]-2-hydroxypropyl] (cyclohexylmethyl)phosphinic acid) (to preclude $\mathrm{GABA}_{\mathrm{B}} \mathrm{R}$-dependent interaction between synapses) (Karson et al., 2009) were present for these experiments. The light-evoked IPSCs elicited $0.2 \mathrm{~s}$ after focal ACh induction of an IPSC burst were inhibited by $34 \%$ (from $136 \pm 25$ to $90 \pm 17$ pA; $p<0.05 ; n=9$; Fig. $8 D$, red trace; $E)$. Conversely, repetitive light exposure ( $5 \mathrm{~ms}$ pulses; $10 \mathrm{~Hz}$ for $4 \mathrm{~s}$ ) elicited a train of summated IPSCs (Fig. $8 F$, red trace) that reduced ACh-induced IPSCs (Fig. $8 F$, black trace) elicited $0.2 \mathrm{~s}$ later by $49 \%$ (from $35 \pm 8$ to $18 \pm 2$ pC; $p<0.05$; Fig. $8 G ; n=7$ ), perhaps by transmitter depletion. These data are consistent with the hypothesis that the PV interneurons account for much of the GABA release resulting from activation of presynaptic $\alpha 3 \beta 4$ nAChRs.

\section{Optogenetic stimulation of $\mathrm{ACh}$ release evokes $\mathrm{nAChR}$ - dependent IPSCs in pyramidal cells}

Finally, our hypothesis predicts that selective stimulation of cholinergic fibers should induce nAChR-dependent GABA release. To test this prediction, we used the viral vector method to deliver ChR2 into cells of the medial septum/diagonal band of Broca, which project their axons extensively throughout the hippocampus (Mesulam et al., 1983). This resulted in transgene expression in cholinergic axons in the hippocampus (Fig. 9A,B). In the presence of NBQX, [(1S)-1[[(7-bromo-1,2,3,4-tetrahydro-2,3-dioxo-5-quinoxalinyl)methyl] amino] ethyl]phosphonic acid hydrochloride (CGP 78608), and atropine, light stimulation of ChR2-labeled axons in acute hippocampal slices resulted in occasional transient occurrences of IPSCs, but the effects were too variable to permit extensive testing. To elicit robust and repeatable ACh-mediated responses, we added the cholinesterase inhibitor eserine $(2 \mu \mathrm{M})$ to increase ACh actions (Pitler and Alger, 1992; Daw et al., 2009), together with a very low concenor by gabazine. ${ }^{*} p<0.05$.
B

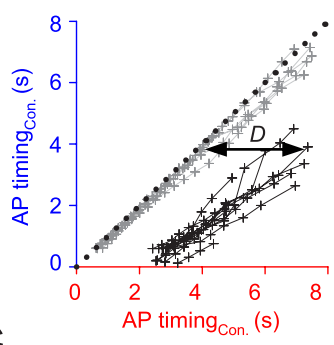

C

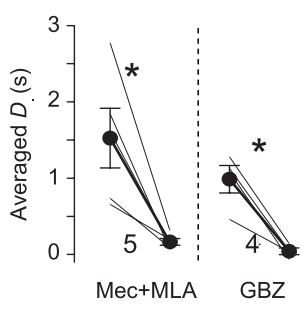

Figure 7. ACh-induced GABA release suppresses pyramidal cell firing; TTXabsent in all experiments. $A$, Action potentials evoked olarizing current injection into a pyramidal cell (blue traces; $\mathrm{ACh}-$ ). One second $\mathrm{ACh}$ applications were timed to end 0.5 (Action potential pairs occurring at the same time after the start of the depolarization fall the black dotted line. The slopes of the lines are the same in both conditions, suggesting that the delay was not caused by changes in postsynaptic cell properties. $C$, Group data showing that the ACh-induced D values were reduced to near zero by MLA plus Mec

tration (10-20 $\mu \mathrm{M})$ of a $\mathrm{K}^{+}$channel blocker, 4-AP, to enhance ACh release (Hull et al., 2009; Petreanu et al., 2009). Trains of blue light pulses ( $5 \mathrm{~ms}$; radius, $\sim 100 \mu \mathrm{m} ; 10$ or $20 \mathrm{~Hz}$ for $2-4 \mathrm{~s}$ ) then evoked strong bursts of IPSCs in 9 of 16 pyramidal cells (baseline frequency, 3.6 $\pm 0.3 \mathrm{~Hz}$, increased to $11.6 \pm 1.9 \mathrm{~Hz} ; p<0.05 ; n=9$; Fig. $9 C, E)$. The responses were eliminated by gabazine $(10 \mu \mathrm{M} ; 0.14 \pm$ $0.06 \mathrm{~Hz} ; p<0.05 ; n=4$; Fig. $9 D, E)$ but were resistant to MLA (50 $\mathrm{nM})$ and $\mathrm{DH} \beta \mathrm{E}(10 \mu \mathrm{M})$, which were present in all experiments (Fig. $9 C, D)$. Mecamylamine $(10 \mu \mathrm{M})$ abolished the light-evoked IPSCs (to $3.9 \pm 0.4 \mathrm{~Hz} ; p>0.05 ; n=5$; Fig. $9 C, E$ ). We confirmed that eserine had no significant effect on the $\alpha 3 \beta 4$ currents in IMR-32 cells (mean response, $82.9 \pm 8.3 \%$; n.s.; $n=6$ ). Hence, selective stimulation of cholinergic fibers, independently of stimulation of other types of axons, glial cells, etc., that are unavoidably activated by electrical stimulation in the slice, can also activate non- $\alpha 7 \mathrm{nAChRs}$ on inhibitory interneurons and trigger GABA release.

Figure $9 F$ illustrates our model of how ACh may activate presynaptic $\alpha 3 \beta 4 \mathrm{nAChRs}$ and, together with axonal T-type $\mathrm{Ca}^{2+}$ channels and $\mathrm{Ca}^{2+}$ stores, induce GABA release.

\section{Discussion}

We find that axonal nAChRs and T-type $\mathrm{Ca}^{2+}$ channels in combination with CICR locally regulate synaptic inhibition. We infer that, by acting primarily on presynaptic $\alpha 3 \beta 4 \mathrm{nAChRs}$, ACh depolarizes CA1 pyramidal cell perisomatic GABAergic axon terminals enough to open $\mathrm{T}$-type $\mathrm{Ca}^{2+}$ channels. The resulting $\mathrm{Ca}^{2+}$ 

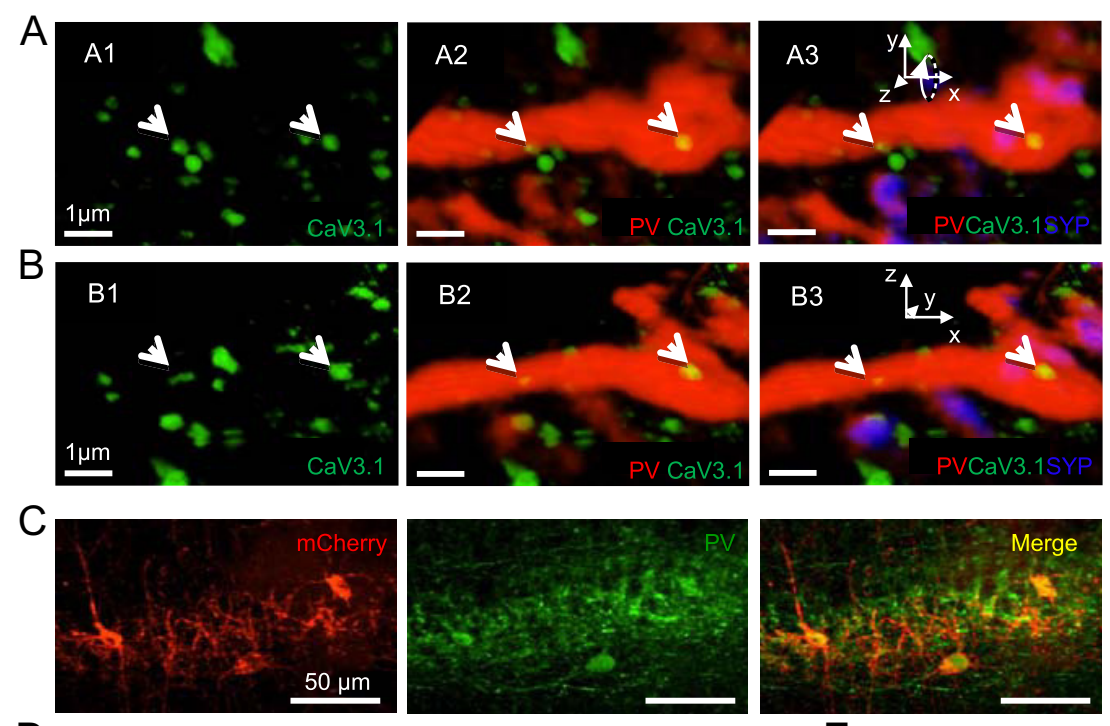

D
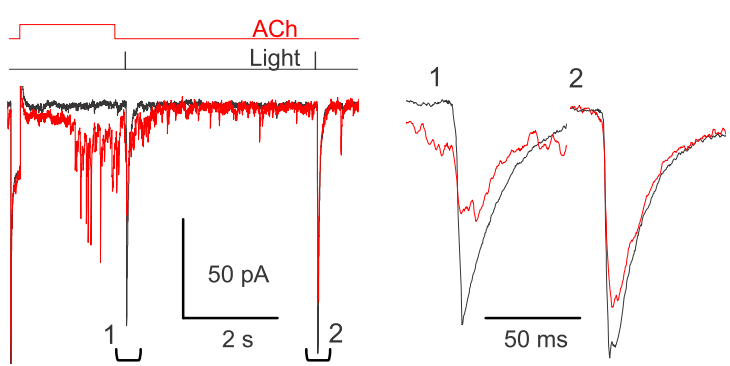

$\mathrm{F}$

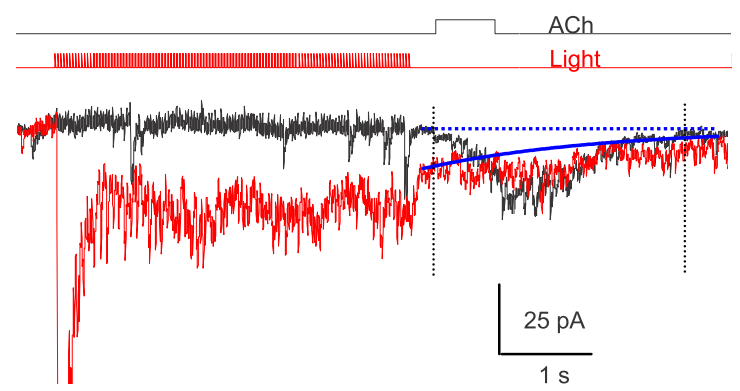

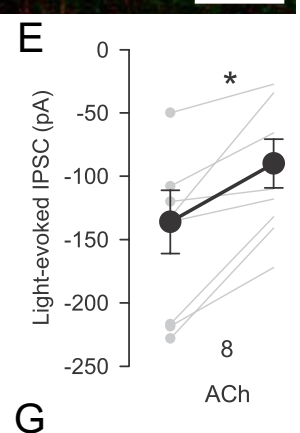

$\mathrm{G}$

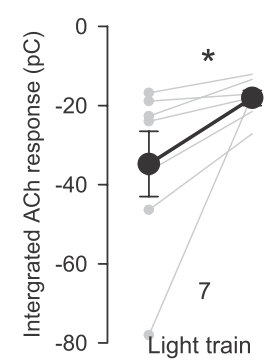

Figure 8. Light stimulation of ChR2-expressing PV-expressing cells evokes GABA release from the same axons that are activated by focal ACh application. A, Cay 3.1-immunoreactive puncta (green) are present on a PV (red) axon labeled with synaptophysin (blue) in CA1 stratum pyramidale. $\boldsymbol{B}$, Same as $A$ rotated into plane by $90^{\circ}$; see inset $x-z$ coordinates. $C a_{v} 3.1$ puncta remained within the PV axon regardless of the angle of rotation, indicating that PV and $\mathrm{Ca}_{\mathrm{v}} 3.1$ labeling are colocalized and not just in close apposition. Scale bars, $1 \mu \mathrm{m}$. C, Expression of ChR2-mCherry (red) in the CA1 region of PV-Cre mice. Sections were immunostained for PV (green) to confirm ChR2-mCherry expression in PV cells (merged image). $\boldsymbol{D}$, Interaction between ACh-evoked and lightevoked, action potential-dependent GABA release. In control conditions, single light pulses elicited large IPSCs (black trace); IPSCs expanded at right. When preceded by an ACh pulse, the light-evoked IPSCs were reduced. Light-evoked IPSC measured from baseline just before the light to the IPSC peak. $\boldsymbol{E}$, Group data for experiments as in $\boldsymbol{B} ;{ }^{*} p<0.05$. $\boldsymbol{F}$, The order of the applications was reversed from the experiment in $\mathbf{D}$ : ACh pulses induced bursts of IPSCs (black trace). When preceded by a $4 \mathrm{~s}$ train of blue light pulses $(5 \mathrm{~ms}, 10 \mathrm{~Hz}$ ), the integrated ACh-induced IPSC burst envelope was reduced. Bursts were integrated from dotted line in control, and from solid blue line after the light train. Both traces are averages of five trials. $\boldsymbol{G}$, Group data for experiments as in $\boldsymbol{F} ;{ }^{*} p<0.05$.

influx triggers CICR and GABA release that can transiently reduce pyramidal cell excitability. This mechanism has several key features, including operation at hyperpolarized membrane potentials, insensitivity to inhibition by presynaptic GPCRs, and independence from action potentials and HVA pathways. Generally, presynaptic neurotransmitter receptors either inhibit or amplify the action potential-initiated, HVA-dependent release process (Vizi and Lendvai, 1999). A notable exception is the highly $\mathrm{Ca}^{2+}$-permeable $\alpha 7 \mathrm{nAChR}$, which, in combination with CICR, triggers significant transmitter release when present on nerve

terminals (Sharma and Vijayaraghavan, 2003; Sharma et al., 2008). Other presynaptic non- $\alpha 7$ nAChRs operate in conjunction with HVAs (Léna and Changeux, 1997; Kulak et al., 2001) and modify the conventional release process. Our finding that activation of $\mathrm{Ca}_{v} 3.1 \mathrm{~T}$-type $\mathrm{Ca}^{2+}$ channels by presynaptic $\alpha 3 \beta 4 \mathrm{nAChRs} \mathrm{con-}$ stitutes a novel GABA release mechanism.

The existence of $\alpha 3 \beta 4 \mathrm{nAChRs}$ near glutamatergic, but not GABAergic, terminals has been proposed (Alkondon and Albuquerque, 2002; Kawa, 2007; Liu et al., 2007; Albuquerque et al., 2009) on the basis of TTX-insensitive transmitter release induced by globally applied nicotinic agonists. In some experiments, $\alpha 3 \beta 4 \mathrm{nAChRs}$ elicited only action potential-dependent IPSCs (Alkondon and Albuquerque, 2002; Zhu et al., 2005), suggesting that ACh activated distant axonal or somatodendritic receptors. Lack of a specific antibody for $\alpha 3 \beta 4$ nAChRs prevents a precise determination of their localization. The small radius of action of focal microiontophoresis (Fig. 1C,D) showed that the $\alpha 3 \beta 4 \mathrm{nAChRs}$ and T-type $\mathrm{Ca}^{2+}$ channels are reasonably close to GABAergic synapses. While $\sim 50 \%$ of the $\alpha 3 \beta 4$ nAChR-induced GABA release is $\mathrm{Cd}^{2+}$ sensitive, the rest is not, suggesting that increases in $\left[\mathrm{Ca}^{2+}\right]_{\mathrm{i}}$ triggered directly or indirectly by $\alpha 3 \beta 4 \mathrm{nAChRs}$ could be significant (Fig. 2) (cf. Kawa, 2007). The net influence of different $\mathrm{Ca}^{2+}$ sources on transmitter release will depend on the location of channels, terminal geometry, etc. (Bucurenciu et al., 2008, 2010).

T-type $\mathrm{Ca}^{2+}$ channels differ markedly from HVA channels. They are largely unaffected by GPCR-dependent regulatory mechanisms that alter HVA function (Lambert et al., 2006) (but cf. Bender et al., 2010). They open in response to small depolarizations from the resting potential, so they are well adapted to sense modest, local stimulation, such as the nonsynaptic actions of neurotransmitters like ACh that can act by volume conduction (Vizi and Lendvai, 1999). Ordinarily, the contribution of T-type $\mathrm{Ca}^{2+}$ channels to GABA release in hippocampus is overwhelmed by rapid and massive $\mathrm{Ca}^{2+}$ influx through HVA channels during action potential-initiated transmission (Hefft and Jonas, 2005). With local ACh stimulation, the occurrence of multiple, brief nAChR openings could transiently but repeatedly activate T-type $\mathrm{Ca}^{2+}$ channels without inactivating them. Importantly, opening of only a few HVA channels is sufficient for GABA release from PV cells (Bucurenciu et al., 2010). Thus, in conjunction with $\mathrm{Ca}^{2+}$ provided by CICR, T-type $\mathrm{Ca}^{2+}$ channels could increase enough $\left[\mathrm{Ca}^{2+}\right]$ within the tiny axon terminals to trigger release. Colocalization of T-type $\mathrm{Ca}^{2+}$ channels and nAChRs may thus extend the dynamic range of synaptic communication to stimuli that are 
below action potential threshold. A cooperative arrangement of $\alpha 3 \beta 4 \mathrm{nAChRs}$ and T-type $\mathrm{Ca}^{2+}$ channels may be particularly advantageous because $\alpha 3 \beta 4 \mathrm{nAChRs}$ are subject to strong inward rectification caused by intracellular polyamines (Haghighi and Cooper, 2000). The decrease in $\alpha 3 \beta 4 \mathrm{nAChR}$ conductance with strong depolarizations will prevent outward current from shunting the slower and smaller T-type $\mathrm{Ca}^{2+}$ channelmediated depolarization and, hence, could be especially significant in facilitating transmitter release initiated by these channels. A very recent paper describes finding $\mathrm{Ca}_{\mathrm{v}} 3.2 \mathrm{~T}$-type $\mathrm{Ca}^{2+}$ channel at the active zones of certain cortical glutamatergic synapses where they regulate glutamate release in conjunction with $\mathrm{HCN} 1$ channels (Huang et al., 2011). In that system, nAChRs were not involved and T-type $\mathrm{Ca}^{2+}$ channels were not found on inhibitory cells. It will be interesting to learn how general the association between T-type $\mathrm{Ca}^{2+}$ channels and release is, and whether the resistance to regulation by presynaptic GPCRs that we report is a universal property of release processes governed by these channels. The existence of two systems for transmitter release could allow for switching between different regulatory modes occurs as circumstances vary.

Neurotransmitter release mediated by T-type $\mathrm{Ca}^{2+}$ channels has a delayed onset and persistent time course when compared with HVA-mediated release. Persistent, action potential-induced, asynchronous GABA release (Hefft and Jonas, 2005; Daw et al., 2009; Karson et al., 2009) is suited to integrating signals over longer durations than is possible with fast synaptic transmission. Asynchronous release processes reflect loose coupling between $\mathrm{Ca}^{2+}$ influx and the release mechanism (Hefft and Jonas, 2005), and may involve a distinct $\mathrm{Ca}^{2+}$ sensor (Sun et al., 2007). In our experiments, bath application of EGTA-AM revealed loose coupling between T-type $\mathrm{Ca}^{2+}$ channels and GABA release. T-type $\mathrm{Ca}^{2+}$ channels could conceivably contribute to asynchronous transmission in other cases as well.

T-type $\mathrm{Ca}^{2+}$ channels are involved in nonaxonal neurotransmitter release. In leech cardiac neurons, they exist throughout the neuritic tree and control graded postsynaptic responses (Ivanov and Calabrese, 2000). T-type $\mathrm{Ca}^{2+}$ channels mediate hormone release from neuroendocrine cells (Carbone et al., 2006), GABA release at reciprocal dendrodendritic synapses in the olfactory bulb (Egger et al., 2003, 2005), and release from retinal bipolar cells (Pan et al., 2001). In some spinal neurons, $\mathrm{Ni}^{2+}$ and mibefradil reduce spontaneous mEPSCs without affecting evoked EPSCs (Bao et al., 1998), suggesting that $\mathrm{T}$-type $\mathrm{Ca}^{2+}$ channels might be involved, although these agents also inhibit R-type $\mathrm{Ca}^{2+}$ channels (Catterall et al., 2005). We found that the selective T-type $\mathrm{Ca}^{2+}$ channel antagonist,

Pyramidal cell soma

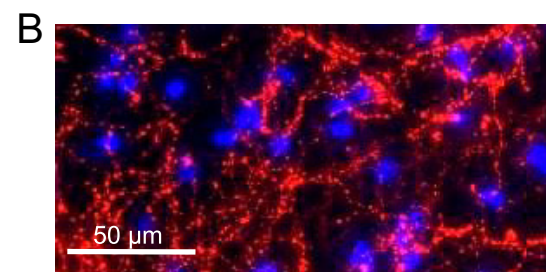

D
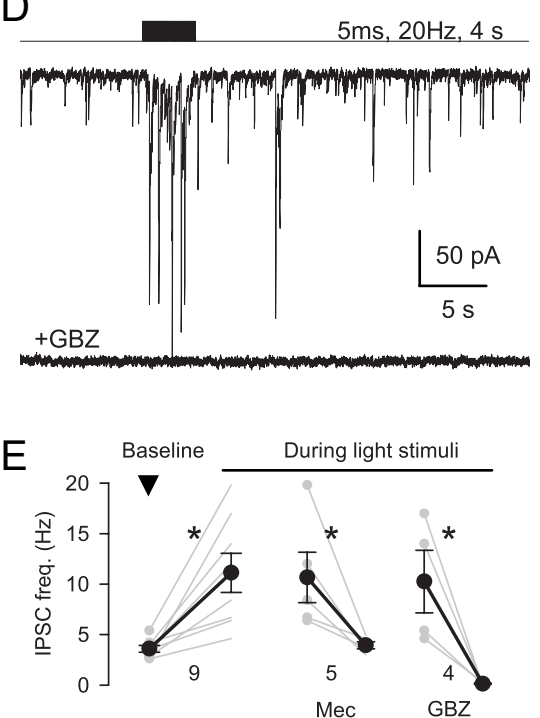

$\mathrm{Mec}$
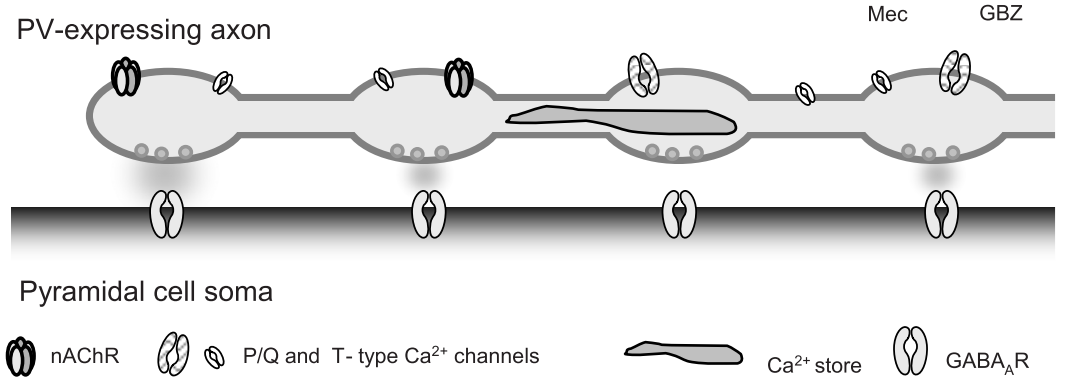

Figure 9. Endogenous $A C h$ evokes $n A C h R$-dependent $G A B A$ release. $A$, Expression of $m$ Cherry in cholinergic fibers in hippocamof ChR2-mCherry in cholinergic fibers in CA1 6 weeks after septal injection. DAPI staining (blue) shows cell nuclei. C, Stimulation of cholinergic fibers in a hippocampal slice by trains of blue light pulses evoked a barrage of IPSCs in a CA1 pyramidal cell (2 $\mu \mathrm{M}$

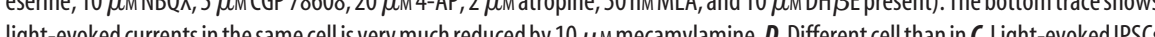
are blocked by gabazine $(10 \mu \mathrm{M})$. $\boldsymbol{E}$, Group data of mean IPSC frequency in baseline (prestimulus) conditions and during train stimulation. ${ }^{*} p<0.05 . F$, Schematic model summarizing the conclusions of this report.

TTA-P2 (Dreyfus et al., 2010), also antagonized ACh-induced GABA release, which strengthened the case for these channels in conventional release.

We used $\mathrm{Ca}_{\mathrm{v}} 3.1$ labeling in combination with immunofluorescent markers for axons (Taul protein), presynaptic terminals (synaptophysin), and specific interneurons (PV) to identify $\mathrm{Ca}_{\mathrm{v}} 3.1$ on hippocampal interneuron terminals. Pharmacological evidence pointed to the involvement of $\mathrm{Ca}_{\mathrm{v}} 3.1$ or 3.3 channels, rather than $\mathrm{Ca}_{\mathrm{v}} 3.2$, which are blocked by low concentrations of $\mathrm{Ni}^{2+}\left(\mathrm{IC}_{50}=12 \mu \mathrm{M}\right)$ (Catterall et al., 2005). $\mathrm{Ca}_{\mathrm{v}} 3.3$ channels are only found in the adult striatum (McRory et al., 2001), whereas $\mathrm{Ca}_{\mathrm{v}} 3.1$ is ubiquitous. Interneurons within s. pyramidale express $\mathrm{Ca}_{\mathrm{v}} 3$ channels on their somatodendritic regions, and there is heavy staining for these channels in CA1 s. pyramidale, amid a dense mesh of basket cell axons (McKay et al., 2006). $\mathrm{Ca}_{\mathrm{v}} 3.1$ was not detected on axon terminals, but a low density of T-type $\mathrm{Ca}^{2+}$ channels on inhibitory axons might have been below the resolu- 
tion of the methods used (McKay et al., 2006). Recently T-type (and R-type) $\mathrm{Ca}^{2+}$ channels were found on the axon initial segments (AISs), although not axon terminals, of cells in the cochlear nucleus (Bender and Trussell, 2009; Bender et al., 2010). T-type $\mathrm{Ca}^{2+}$ channels on the AISs affect the generation of axonal complex spikes, and thereby strongly influence synaptic output. With TTX present, the T-type $\mathrm{Ca}^{2+}$ channel-initiated $\mathrm{Ca}^{2+}$ influx in cochlear nucleus cells remained confined to the AIS, suggesting that T-type $\mathrm{Ca}^{2+}$ channels at the AIS have different functions than those near axon terminals.

Perisomatic-targeting PV interneurons include both axoaxonic cells that narrowly innervate pyramidal cell axon initial segments, and basket cells having a wider range of somatodendritic synaptic contacts and different functional roles (Freund and Katona, 2007; Klausberger and Somogyi, 2008). We could not distinguish between axoaxonic and basket cells, and doing so will be an important future task. We focused on PV-expressing interneurons, and our data do not exclude a role for T-type $\mathrm{Ca}^{2+}$ channels on CCK-expressing or other interneurons in CA1. Indeed, $\mathrm{Ca}_{\mathrm{v}} 3.1$ was detected on some non-PV-labeled profiles, but testing other candidates went beyond the scope of this investigation. Although we observed that PV cell $\alpha 3 \beta 4 \mathrm{nAChRs}$ were significant effectors of the ACh actions on GABA release, we did observe a component that was attributable to $\alpha 7 \mathrm{nAChRs,} \mathrm{which}$ are expressed on CCK - basket cells (Freund, 2003), and this avenue remains to be explored.

Because the nAChR-Ca 3.1 mechanism does not require action potential firing, it is not expected to engage the wide dispersion of GABAergic inhibition triggered by somatic action potentials. Normally, however, stimulation of the local (terminal and preterminal) nAChRs (Fig. 1) may trigger action potentials that could propagate laterally throughout the axonal network. T-type $\mathrm{Ca}^{2+}$ channels participate in the generation of thalamocortical rhythms (Huguenard and Prince, 1992; Huguenard and McCormick, 2007) and the oscillations associated with absence epileptic seizures (Huguenard, 2002) and antagonists of these channels are used therapeutically in these seizure disorders. By reducing the nicotinic activation of GABA inhibition in the hippocampus, such treatments could have ancillary effects on epileptiform activity and even nicotine use as well. The high incidence of tobacco use among schizophrenics is often interpreted as an attempt at "selfmedication" by the individuals (D'Souza and Markou, 2011). If schizophrenia involves deficits in perisomatic, PV cellmediated inhibition (Lewis et al., 2005), then it may be significant that the mechanism that we have discovered would increase GABA release from these cells, perhaps partially compensating for the deficit.

\section{References}

Albuquerque EX, Pereira EF, Alkondon M, Rogers SW (2009) Mammalian nicotinic acetylcholine receptors: from structure to function. Physiol Rev 89:73-120.

Alger BE (2002) Retrograde signaling in the regulation of synaptic transmission: focus on endocannabinoids. Prog Neurobiol 68:247-286.

Alkondon M, Albuquerque EX (2002) A non-alpha7 nicotinic acetylcholine receptor modulates excitatory input to hippocampal CA1 interneurons. J Neurophysiol 87:1651-1654.

Atasoy D, Aponte Y, Su HH, Sternson SM (2008) A FLEX switch targets channelrhodopsin-2 to multiple cell types for imaging and long-range circuit mapping. J Neurosci 28:7025-7030.

Augustine GJ, Santamaria F, Tanaka K (2003) Local calcium signaling in neurons. Neuron 40:331-346.

Bao J, Li JJ, Perl ER (1998) Differences in $\mathrm{Ca}^{2+}$ channels governing gener- ation of miniature and evoked excitatory synaptic currents in spinal laminae I and II. J Neurosci 18:8740-8750.

Bartos M, Vida I, Jonas P (2007) Synaptic mechanisms of synchronized gamma oscillations in inhibitory interneuron networks. Nat Rev Neurosci 8:45-56.

Bender KJ, Trussell LO (2009) Axon initial segment $\mathrm{Ca}^{2+}$ channels influence action potential generation and timing. Neuron 61:259-271.

Bender KJ, Ford CP, Trussell LO (2010) Dopaminergic modulation of axon initial segment calcium channels regulates action potential initiation. Neuron 68:500-511.

Binder LI, Frankfurter A, Rebhun LI (1985) The distribution of tau in the mammalian central nervous system. J Cell Biol 101:1371-1378.

Bucurenciu I, Kulik A, Schwaller B, Frotscher M, Jonas P (2008) Nanodomain coupling between $\mathrm{Ca}^{2+}$ channels and $\mathrm{Ca}^{2+}$ sensors promotes fast and efficient transmitter release at a cortical GABAergic synapse. Neuron 57:536-545.

Bucurenciu I, Bischofberger J, Jonas P (2010) A small number of open $\mathrm{Ca}^{2+}$ channels trigger transmitter release at a central GABAergic synapse. Nat Neurosci 13:19-21.

Carbone E, Giancippoli A, Marcantoni A, Guido D, Carabelli V (2006) A new role for T-type channels in fast "low-threshold" exocytosis. Cell Calcium 40:147-154.

Catterall WA, Perez-Reyes E, Snutch TP, Striessnig J (2005) International Union of Pharmacology. XLVIII. Nomenclature and structurefunction relationships of voltage-gated calcium channels. Pharmacol Rev 57:411-425.

Celio MR, Baier W, Schärer L, de Viragh PA, Gerday C (1988) Monoclonal antibodies directed against the calcium binding protein parvalbumin. Cell Calcium 9:81-86.

Chen Y, Sharp AH, Hata K, Yunker AM, Polo-Parada L, Landmesser LT, McEnery MW (2007) Site-directed antibodies to low-voltage-activated calcium channel $\mathrm{Ca}_{\mathrm{v}} 3.3$ (ALPHA1I) subunit also target neural cell adhesion molecule-180. Neuroscience 145:981-996.

Cueni L, Canepari M, Adelman JP, Lüthi A (2009) $\mathrm{Ca}^{2+}$ signaling by T-type $\mathrm{Ca}^{2+}$ channels in neurons. Pflugers Arch 457:1161-1172.

Daw MI, Tricoire L, Erdelyi F, Szabo G, McBain CJ (2009) Asynchronous transmitter release from cholecystokinin-containing inhibitory interneurons is widespread and target-cell independent. J Neurosci 29:11112-11122.

Donnelly-Roberts DL, Arneric SP, Sullivan JP (1995) Functional modulation of human "ganglionic-like" neuronal nicotinic acetylcholine receptors (nAChRs) by L-type calcium channel antagonists. Biochem Biophys Res Commun 213:657-662.

Drake CT, Milner TA (2002) Mu opioid receptors are in discrete hippocampal interneuron subpopulations. Hippocampus 12:119-136.

Dreyfus FM, Tscherter A, Errington AC, Renger JJ, Shin HS, Uebele VN, Crunelli V, Lambert RC, Leresche N (2010) Selective T-type calcium channel block in thalamic neurons reveals channel redundancy and physiological impact of I (T)window. J Neurosci 30:99-109.

D'Souza MS, Markou A (2011) Schizophrenia and tobacco smoking comorbidity: nAChR agonists in the treatment of schizophrenia-associated cognitive deficits. Neuropharmacology. Advance online publication. Retrieved August 11, 2011. doi:10.1016/j.neuropharm.2011.01.044.

Egger V, Svoboda K, Mainen ZF (2003) Mechanisms of lateral inhibition in the olfactory bulb: efficiency and modulation of spike-evoked calcium influx into granule cells. J Neurosci 23:7551-7558.

Egger V, Svoboda K, Mainen ZF (2005) Dendrodendritic synaptic signals in olfactory bulb granule cells: local spine boost and global low-threshold spike. J Neurosci 25:3521-3530.

Ernst WL, Zhang Y, Yoo JW, Ernst SJ, Noebels JL (2009) Genetic enhancement of thalamocortical network activity by elevating alpha $1 \mathrm{~g}$-mediated low-voltage-activated calcium current induces pure absence epilepsy. J Neurosci 29:1615-1625.

Freund TF (2003) Interneuron Diversity series: rhythm and mood in perisomatic inhibition. Trends Neurosci 26:489-495.

Freund TF, Katona I (2007) Perisomatic inhibition. Neuron 56:33-42.

Haghighi AP, Cooper E (2000) A molecular link between inward rectification and calcium permeability of neuronal nicotinic acetylcholine $\alpha 3 \beta 4$ and $\alpha 4 \beta 2$ receptors. J Neurosci 20:529-541.

Harvey SC, Luetje CW (1996) Determinants of competitive antagonist sensitivity on neuronal nicotinic receptor beta subunits. J Neurosci 16:3798-3806. 
Hefft S, Jonas P (2005) Asynchronous GABA release generates long-lasting inhibition at a hippocampal interneuron-principal neuron synapse. Nat Neurosci 8:1319-1328.

Honer WG, Hu L, Davies P (1993) Human synaptic proteins with a heterogenous distribution in cerebellum and visual cortex. Brain Res 609:9-20.

Huang Z, Lujan R, Kadurin I, Uebele VN, Renger JJ, Dolphin AC, Shah MM (2011) Presynaptic HCN1 channels regulate Cav3.2 activity and neurotransmission at select cortical synapses. Nat Neurosci $14: 478-486$

Huguenard JR (2002) Block of T-type $\mathrm{Ca}^{2+}$ channels is an important action of succinimide antiabsence drugs. Epilepsy Curr 2:49-52.

Huguenard JR, McCormick DA (2007) Thalamic synchrony and dynamic regulation of global forebrain oscillations. Trends Neurosci 30:350-356.

Huguenard JR, Prince DA (1992) A novel T-type current underlies prolonged $\mathrm{Ca}^{2+}$-dependent burst firing in GABAergic neurons of rat thalamic reticular nucleus. J Neurosci 12:3804-3817.

Hull C, Adesnik H, Scanziani M (2009) Neocortical disynaptic inhibition requires somatodendritic integration in interneurons. J Neurosci 29:8991-8995.

Ivanov AI, Calabrese RL (2000) Intracellular $\mathrm{Ca}^{2+}$ dynamics during spontaneous and evoked activity of leech heart interneurons: lowthreshold Ca currents and graded synaptic transmission. J Neurosci 20:4930-4943.

Karson MA, Tang AH, Milner TA, Alger BE (2009) Synaptic cross talk between perisomatic-targeting interneuron classes expressing cholecystokinin and parvalbumin in hippocampus. J Neurosci 29:4140-4154.

Kawa K (2007) Inhibitory synaptic transmission in area postrema neurons of the rat showing robust presynaptic facilitation mediated by nicotinic ACh receptors. Brain Res 1130:83-94.

Khiroug L, Giniatullin R, Klein RC, Fayuk D, Yakel JL (2003) Functional mapping and $\mathrm{Ca}^{2+}$ regulation of nicotinic acetylcholine receptor channels in rat hippocampal CA1 neurons. J Neurosci 23:9024-9031.

Kim D, Song I, Keum S, Lee T, Jeong MJ, Kim SS, McEnery MW, Shin HS (2001) Lack of the burst firing of thalamocortical relay neurons and resistance to absence seizures in mice lacking $\alpha_{1 \mathrm{G}}$ T-type $\mathrm{Ca}^{2+}$ channels. Neuron 31:35-45.

Klausberger T, Somogyi P (2008) Neuronal diversity and temporal dynamics: the unity of hippocampal circuit operations. Science 321:53-57.

Klausberger T, Marton LF, O’Neill J, Huck JH, Dalezios Y, Fuentealba P, Suen WY, Papp E, Kaneko T, Watanabe M, Csicsvari J, Somogyi P (2005) Complementary roles of cholecystokinin- and parvalbumin-expressing GABAergic neurons in hippocampal network oscillations. J Neurosci 25:9782-9793.

Klugmann M, Symes CW, Leichtlein CB, Klaussner BK, Dunning J, Fong D, Young D, During MJ (2005) AAV-mediated hippocampal expression of short and long Homer 1 proteins differentially affect cognition and seizure activity in adult rats. Mol Cell Neurosci 28:347-360.

Kovács K, Sík A, Ricketts C, Timofeev I (2010) Subcellular distribution of low-voltage activated T-type $\mathrm{Ca}^{2+}$ channel subunits $\left(\mathrm{Ca}_{\mathrm{v}} 3.1\right.$ and $\left.\mathrm{Ca}_{\mathrm{v}} 3.3\right)$ in reticular thalamic neurons of the cat. J Neurosci Res 88:448-460.

Kulak JM, McIntosh JM, Yoshikami D, Olivera BM (2001) Nicotine-evoked transmitter release from synaptosomes: functional association of specific presynaptic acetylcholine receptors and voltage-gated calcium channels. J Neurochem 77:1581-1589.

Lambert RC, Bessaih T, Leresche N (2006) Modulation of neuronal T-type calcium channels. CNS Neurol Disord Drug Targets 5:611-627.

Léna C, Changeux JP (1997) Role of $\mathrm{Ca}^{2+}$ ions in nicotinic facilitation of GABA release in mouse thalamus. J Neurosci 17:576-585.

Lewis DA, Hashimoto T, Volk DW (2005) Cortical inhibitory neurons and schizophrenia. Nat Rev Neurosci 6:312-324.

Liu Z, Otsu Y, Vasuta C, Nawa H, Murphy TH (2007) Action-potentialindependent GABAergic tone mediated by nicotinic stimulation of immature striatal miniature synaptic transmission. J Neurophysiol 98:581-593.

Lu Y, Grady S, Marks MJ, Picciotto M, Changeux JP, Collins AC (1998) Pharmacological characterization of nicotinic receptor-stimulated GABA release from mouse brain synaptosomes. J Pharmacol Exp Ther 287:648-657.

Luo S, Kulak JM, Cartier GE, Jacobsen RB, Yoshikami D, Olivera BM, McIntosh JM (1998) $\alpha$-conotoxin AuIB selectively blocks $\alpha 3 \beta 4$ nic- otinic acetylcholine receptors and nicotine-evoked norepinephrine release. J Neurosci 18:8571-8579.

MacDermott AB, Role LW, Siegelbaum SA (1999) Presynaptic ionotropic receptors and the control of transmitter release. Annu Rev Neurosci 22:443-485.

McGehee DS, Role LW (1996) Presynaptic ionotropic receptors. Curr Opin Neurobiol 6:342-349.

McKay BE, McRory JE, Molineux ML, Hamid J, Snutch TP, Zamponi GW, Turner RW (2006) $\mathrm{Ca}_{\mathrm{v}} 3$ T-type calcium channel isoforms differentially distribute to somatic and dendritic compartments in rat central neurons. Eur J Neurosci 24:2581-2594.

McQuiston AR, Madison DV (1999) Nicotinic receptor activation excites distinct subtypes of interneurons in the rat hippocampus. J Neurosci 19:2887-2896.

McRory JE, Santi CM, Hamming KS, Mezeyova J, Sutton KG, Baillie DL, Stea A, Snutch TP (2001) Molecular and functional characterization of a family of rat brain T-type calcium channels. J Biol Chem 276:3999-4011.

Mesulam MM, Mufson EJ, Wainer BH, Levey AI (1983) Central cholinergic pathways in the rat: an overview based on an alternative nomenclature (Ch1-Ch6). Neuroscience 10:1185-1201.

Mithani S, Atmadja S, Baimbridge KG, Fibiger HC (1987) Neurolepticinduced oral dyskinesias: effects of prograbide and lack of correlation with regional changes in glutamic acid decarboylase and choline acetyltransferase activities. Psychopharmacology (Berl) 93:94-100.

Morales M, Hein K, Vogel Z (2008) Hippocampal interneurons co-express transcripts encoding the alpha 7 nicotinic receptor subunit and the cannabinoid receptor 1 . Neuroscience 152:70-81.

Neher E (1998) Vesicle pools and $\mathrm{Ca}^{2+}$ microdomains: new tools for understanding their roles in neurotransmitter release. Neuron 20:389-399.

Neher E, Sakaba T (2008) Multiple roles of calcium ions in the regulation of neurotransmitter release. Neuron 59:861-872.

Nelson ME, Wang F, Kuryatov A, Choi CH, Gerzanich V, Lindstrom J (2001) Functional properties of human nicotinic AChRs expressed by IMR-32 neuroblastoma cells resemble those of alpha3beta4 AChRs expressed in permanently transfected HEK cells. J Gen Physiol 118:563-582.

Ohno-Shosaku T, Maejima T, Kano M (2001) Endogenous cannabinoids mediate retrograde signals from depolarized postsynaptic neurons to presynaptic terminals. Neuron 29:729-738.

Pan ZH, Hu HJ, Perring P, Andrade R (2001) T-type $\mathrm{Ca}^{2+}$ channels mediate neurotransmitter release in retinal bipolar cells. Neuron 32:89-98.

Parajuli LK, Fukazawa Y, Watanabe M, Shigemoto R (2010) Subcellular distribution of alpha1G subunit of T-type calcium channel in the mouse dorsal lateral geniculate nucleus. J Comp Neurol 518:4362-4374.

Peters A, Palay SL, Webster Hd (1991) The fine structure of the nervous system. New York: Oxford UP.

Petreanu L, Mao T, Sternson SM, Svoboda K (2009) The subcellular organization of neocortical excitatory connections. Nature 457:1142-1145.

Pitler TA, Alger BE (1992) Cholinergic excitation of GABAergic interneurons in the rat hippocampal slice. J Physiol 450:127-142.

Ragozzino D, Barabino B, Fucile S, Eusebi F (1998) $\mathrm{Ca}^{2+}$ permeability of mouse and chick nicotinic acetylcholine receptors expressed in transiently transfected human cells. J Physiol 507:749-757.

Sharma G, Vijayaraghavan S (2003) Modulation of presynaptic store calcium induces release of glutamate and postsynaptic firing. Neuron 38:929-939.

Sharma G, Grybko M, Vijayaraghavan S (2008) Action potential-independent and nicotinic receptor-mediated concerted release of multiple quanta at hippocampal CA3-mossy fiber synapses. J Neurosci 28:2563-2575.

Shibuki K, Hishida R, Murakami H, Kudoh M, Kawaguchi T, Watanabe M, Watanabe S, Kouuchi T, Tanaka R (2003) Dynamic imaging of somatosensory cortical activity in the rat visualized by flavoprotein autofluorescence. J Physiol 549:919-927.

Shipe WD, Barrow JC, Yang ZQ, Lindsley CW, Yang FV, Schlegel KA, Shu Y, Rittle KE, Bock MG, Hartman GD, Tang C, Ballard JE, Kuo Y, Adarayan ED, Prueksaritanont T, Zrada MM, Uebele VN, Nuss CE, Connolly TM, Doran SM, et al. (2008) Design, synthesis, and evaluation of a novel 4-aminomethyl-4-fluoropiperidine as a T-type $\mathrm{Ca}^{2+}$ channel antagonist. J Med Chem 51:3692-3695.

Sudweeks SN, Yakel JL (2000) Functional and molecular characterization of neuronal nicotinic ACh receptors in rat CA1 hippocampal neurons. J Physiol 527:515-528. 
Sun J, Pang ZP, Qin D, Fahim AT, Adachi R, Südhof TC (2007) A dual$\mathrm{Ca}^{2+}$-sensor model for neurotransmitter release in a central synapse. Nature 450:676-682.

Tedford HW, Zamponi GW (2006) Direct G protein modulation of $\mathrm{Ca}_{\mathrm{v}} 2$ calcium channels. Pharmacol Rev 58:837-862.

Uebele VN, Nuss CE, Fox SV, Garson SL, Cristescu R, Doran SM, Kraus RL, Santarelli VP, Li Y, Barrow JC, Yang ZQ, Schlegel KA, Rittle KE, Reger TS, Bednar RA, Lemaire W, Mullen FA, Ballard JE, Tang C, Dai G, et al. (2009) Positive allosteric interaction of structurally diverse T-type calcium channel antagonists. Cell Biochem Biophys 55:81-93.

Verkhratsky A (2005) Physiology and pathophysiology of the calcium store in the endoplasmic reticulum of neurons. Physiol Rev 85:201-279.

Vinet J, Sík A (2006) Expression pattern of voltage-dependent calcium channel subunits in hippocampal inhibitory neurons in mice. Neuroscience 143:189-212.

Vizi ES, Lendvai B (1999) Modulatory role of presynaptic nicotinic recep- tors in synaptic and non-synaptic chemical communication in the central nervous system. Brain Res Rev 30:219-235.

Wilson RI, Nicoll RA (2001) Endogenous cannabinoids mediate retrograde signalling at hippocampal synapses. Nature 410:588-592.

Wilson RI, Kunos G, Nicoll RA (2001) Presynaptic specificity of endocannabinoid signaling in the hippocampus. Neuron 31:453-462.

Wonnacott S (1997) Presynaptic nicotinic ACh receptors. Trends Neurosci 20:92-98.

Wu LG, Saggau P (1997) Presynaptic inhibition of elicited neurotransmitter release. Trends Neurosci 20:204-212.

Zhang F, Gradinaru V, Adamantidis AR, Durand R, Airan RD, de Lecea L, Deisseroth K (2010) Optogenetic interrogation of neural circuits: technology for probing mammalian brain structures. Nat Protoc 5:439-456.

Zhu PJ, Stewart RR, McIntosh JM, Weight FF (2005) Activation of nicotinic acetylcholine receptors increases the frequency of spontaneous GABAergic IPSCs in rat basolateral amygdala neurons. J Neurophysiol 94:3081-3091. 